\title{
COMMENTS
}

\section{HOLD THE CORKS: A COMMENT ON PAUL CARRINGTON'S "SUBSTANCE" AND “PROCEDURE" IN THE RULES ENABLING ACT}

\author{
STEPHEN B. BURBANK*
}

This problem at first approach seems difficult. The Advisory Committee found very little difficulty with it. It is astomishing how many decisions there are in the Supreme Court and the otlier courts which define the difference between procedure, on the one liand, and substantive rights, on the other.

William D. Mitchell, Chairman of the original Advisory Committee, to the participants in the Cleveland Institute on the Federal Rules (1938).

I frequently am dissatisfied with myself, because after more than two years of struggling with practice and procedure, when a question arises as to whether a inatter is procedure or substance, iny mind is murky on the subject and I am unable to reach a conclusion in which I have confidence whenever the question is at all debatable. The truth is that the twilight zone around the dividing line between substance and procedure is a very broad one. If it were not for the fact that the court which inakes these rules will decide whether they were within the authority, we would have very serious difficulties in dealing witl this problem. The general pohicy I liave acted on is that where a difficult question arose as to wliether a matter was substance or procedure and

\footnotetext{
Copyright (C) 1990 by Stephen B. Burbank

* Professor of Law, University of Pennsylvania. A.B., 1968; J.D., 1973, Harvard University. As a result of my articles on the Enabling Acts and court rulemaking, I appeared as an invited witness at hearings on, and otherwise assisted the House Judiciary Coinunittee in developing ainendments to, those statutes. See, eg., Rules Enabling Act of 1985: Hearing on H.R. 2633 and H.R. 3550 Before the Subcomm. on Courts, Civil Liberties, and the Administration of Justice of the House Comm. on the Judiciary, 99th Cong., 1st Sess. 2-48, 90-93, 280-82 (1985) [hereinafter 1985 Hearing]; 131 CoNG. Rec. H11,398 (daily ed. Dec. 9, 1985) (remarks of Rep. Kastenmeier) (thanking author for assisting the Coinmittee on the bill); see also infra note 127. I also testified in Senate hearings, which were limited to the issue of supersession. See Prepared Stateinent of Stephen B. Burbank Before the Subcommittee on Courts and Administrative Practice of the Senate Judiciary Committee, on the Rules Enabling Acts (May 25, 1988) (copy available from author). In preparing this coinment, I have benefited from reading an unpublished manuscript by Laura Macklin. L. Macklin, Federal Court Rulemaking (1989). I also have benefited from coununents by David Beier, Frank Goodman, Leo Levin, Laura Macklin, and Steve Subrin.
} 
I thought the proposed provision was a good one, I have voted to put it in, on the theory that if the Court adopted it, the Court would be likely to hold, if the question ever arises in hitigation, that the natter is a procedural one.

William D. Mitchell to the Hon. George Wharton Pepper, a member of the Advisory Committee (December 19, 1937).

In a recent article in this journal, Paul Carrington offered a coinprehensive statement of his views about the proper function of, including the legal and prudential limits on, court rules proinulgated by the Supreine Court for application in the lower federal courts. ${ }^{1}$ First presented when Professor Carrington was concluding service as a Dean and beginning service as Reporter of tlie Advisory Committee on Civil Rules, ${ }^{2}$ the paper has evolved both in its reach and in the confidence of its couclusions. The changes reflect the enhanced time available to the author and his enduring appetite for education. They also reflect his participation in the recently revived, and surprisingly vigorous, debate about the future of American civil procedure. Indeed, Professor Carrington has assunned the role of chief defender of what he represents as the status quo: a systein of uniforin and trans-substantive national rules, loosely textured and relying to a great exteut on judicial discretion. In his view, such a system, by preserving the appearance of pohtical neutrahty, allows the rulemakers ("technicians") to go about their business without the distractions of interest group politics and yields results that should be a source of satisfaction to all. ${ }^{3}$

In his inost recent article, for the first time, Professor Carrington confronts issues of rulenaking power. Having assisted, albeit in an "obscure and inuffled"4 way, in a successful campaign to defeat repeal of the

1. See Carrington, "Substance" and "Procedure" in the Rules Enabling Act, 1989 DukE L.J. 281 (1989).

2. Dean Carrington presented a paper entitled, "An Appreciation of Walter Wheeler Cook, Erie, and the Rules Enabling Act," to the Section of Civil Procedure of the Association of American Law Schools on January 7, 1988. I was privileged to comment on that paper, as well as a paper by Judge Jack Weinstein. See Burbank, The Chancellor's Boot, 54 BRookLYN L. REv. 31 (1988). This Comment is a revised version of my AALS remarks.

3. See Carrington, supra note 1, at 301-02, 303-07, 326-27; Carrington, Continuing Work on the Civil Rules: The Summons, 63 Notre DAME L. REv. 733 (1988); Carrington, Making Rules to Dispose of Manifestly Unfounded Assertions: An Exorcism of the Bogy of Non-Trans-Substantive Rules of Civil Procedure, 137 U. PA. L. REv. 2067, 2074-85 (1989) [hereinafter Carrington, Bogy]. See also Subrin, Fireworks on the 50th Anniversary of the Federal Rules of Civil Procedure, 73 JUD1CATURE 4 (1989)

4. Carrington, supra note 1 , at 281 . 
supersession clause by Congress, ${ }^{5}$ the author would like us to join in celebrating that event ${ }^{6}$ and to rest assured that-in inatters of power as in other inatters of ruleinaking jurisprudence-all is, if not well, then at least well enough not to worry. ${ }^{7}$

Neither deans nor reporters have tenure, which should make us doubly happy that Paul Carrington is also a professor. The qualities he has brought to the position of Reporter of the Advisory Coinunittee on Civil Rules-independence of mind, receptivity to other points of view, and the awareness that ruleinaking is in an important sense a political

5. Compare Letter from Janet Napolitano, Esq. to Professor Paul Carrington 1-2 (May 13, 1987) (copy available from author) ("I lave been more than tardy in response to your letter raising questions about the proposed amendments to the Rules Enabling Act.... If any active opposition is to be garnered, that work needs to be done in the Senate. Senator DeConcini ... miglit be lielpful to us in this regard if we ask him to be.") with Statement of Paul Carrington to Subcommittee on Courts and Administrative Practice of Senate Judiciary Committee Re: Proposed Deletion of Supersession Provision by the Rules Enabling Act Amendments of 1988, at 1-2 (May 25, 1988) (copy available from autlior) ("I will not draw any conclusion on the wisdom of the proposed revision, in part because I serve the Judicial Conference of the United States, which has voted to take no position with respect to the issue, and also because my own individual opinion, which is all that $I$ could provide, slould lave no particular weiglit in your deliberations, especially so because I may be perceived to have a personal interest in the matter.").

In fact, the Conferenee did take a position on the proposed deletion of the supersession clause, namely the position of "no objection." As explamed in a letter from Judge Gignoux, then Chairman of the Conference's Committee on Rules of Practice and Procedure, to Representative Kastenmeier, Chairman of the House Judiciary Subcommittee:

The Conference defers to your view that the supersession clause is probably unnecessary since the Judicial Code of 1948 eliminated the numerous federal procedural statutes which were the principal reason for the clause. The Conference also is persuaded that it would be unwise to invite litigation clallenging the rulemaking process by those who question the constitutionality of a supersession clause under the Separation of Powers doctrine.

Letter from Hon. Edward T. Gignoux to Hon. Robert W. Kastenmeier 1 (Sept. 24, 1985), reprinted in H.R. REP. No. 422, 99th Cong., 1st Sess. 44 (1985); see also Prepared Statement of Joseph F. Weis Jr., Chairman, Standing Committee on Rules of Practice and Procedure of the Judicial Conferenee, Before the Subcommittee on Courts and Administrative Practice, Committee on the Judiciary, Uunted States Senate, on the Rules Enabling Act of 1987, at 1 (May 25, 1988) [hereinafter Weis Statement] (copy available from author) ("the Conference does not object to the bill's provisions on this subject").

As amended by the Judicial Improvements and Access to Justice Act, Pub. L. No. 100-702, § 401, 102 Stat. 4642, $4648-49$ (1988), 28 U.S.C. § 2072 provides:

(a) The Supreme Court shall have the power to prescribe general rules of practice and procedure and rules of evidence for eases in the United States district courts (including proceedings before magistrates thereof) and courts of appeals.

(b) Sucli rules shall not abridge, enlarge or modify any substantive riglt. All laws in conflict with sucl rules shall be of no further force or effect after such rules have taken effect.

The second sentence of section 2072(b) contains the so-called "supersession clause." For further discussion of the history of its preservation against the House's attempt at repeal, see infro text aecompanying notes $178-79$.

6. "Supersession lives! Long live Supersession!" Carrington, supra note 1, at 281. I had thought of entitling this Cominent, after Cato the Elder, "Supersession Must Be Destroyed." Cf. II Plutarch's Lives 383 (Loeb ed. 1914) ("Carthage must be destroyed"). Professor Carrington's article is, however, about inuch more than supersession, and so is this response.

7. See, e.g., Carrington, supra note 1 , at 326-27. 
enterprise-are badly needed in that enterprise. ${ }^{8}$ Indeed, because Professor Carrington is the Reporter, we have less reason to be worried about one kind of judicial usurpation. His article reflects attention to issues implicating the allocation of federal powers and to the relativity of legal language that, in this context at least, was disdained by Charles Clark as it was by others among Professor Carrington's predecessors. ${ }^{9}$ From its rich and subtle analysis of limitations law $^{10}$ to its ingerrious interpretation of the Enabling Act's supersession clause, ${ }^{11}$ the article is a fitting tribute to the meinory of Walter Wheeler Cook. ${ }^{12}$ Nonetheless, I beheve that Professor Carrington has invited us to the wrong celebration and that there is reason to doubt whether any celebration is im order. Having engaged Professor Carrington's views on generalisin, judicial discretion and pohitical neutrahity elsewhere, ${ }^{13}$ I find his views on rulemaking power no more analytically satisfying, no inore faithful to the facts, and no inore reassuring.

Professor Carrington attempts to demonstrate that, whatever the intent of Congress when it passed the Rules Enabling Act of 1934,14 the Supreine Court has promulgated a number of Federal Rules that regulate aspects of limitations law, either by their terins or by reason of the Court's interpretations. Although at times critical of some of these decisions, Professor Carrington at other times ennbraces thein as authority for prospective rulenaking in the area, the propriety of which he belives is confirmed by functional analysis.

In fact, as I shall demonstrate, Professor Carrington misreads both a number of the Federal Rules and a number of the Court's decisions on which he rehes. Moreover, even if it were true, which it is not, that the Court's fumbles in the himitations game somehow reached the end zone of nornative (or functional) thinking, that hardly would prove that the Court can score in inore important games, or that it can score at all when

8. See, e.g., Burbank, Proposals to Amend Rule 68-Time to Abandon Ship, 19 U. MicH. J.L. REF. 425, 426-31 (1986) (arguing that formal legal analysis and the politics of court rulemaking suggest that the Advisory Committee's basic premises are faulty).

9. See Burbank, The Rules Enabling Act of 1934, 130 U. PA. L. Rev. 1015, 1136-37, 1159-60 $\&$ n.620 (1982).

10. See Carrington, supra note 1 , at $290-93$.

11. See id. at 324-25.

12. See supra note 2.

13. See Burbank, Of Rules and Discretion: The Supreme Court, Federal Rules and Common Law, 63 Notre Dame L. Rev. 693 (1988) [hereinafter Burbank, Rules and Discretion]; Burbank, The Transformation of American Civil Procedure: The Example of Rule 11, 137 U. PA. L. REv. 1925 (1989) [hereinafter Burbank, Transformation].

14. Pub. L. No. 73-415, 48 Stat. 1064 (1934)(codified at 28 U.S.C. § 2072 (1982), amended by Pub. L. No. 100-702, $\S 401$ (a), 102 Stat. 4648 (1988)). The text of the Act, as codified and amended prior to 1988 , is set forth infra at note 115 . 
it plays by the rules. Perhaps, however, unlike Professor Carrington, the Court will realize that the referee already has blown the whistle.

Although those responsible for drafting and explaining the bill that became the Rules Enabling Act of 1934 were not legal realists, ${ }^{15}$ their understanding of "practice and procedure" as used in that bill was informed by the particular legal context in which they labored. Their priinary purpose was to allocate power between the Supreme Court-as rulemaker-and Congress, ${ }^{16}$ with the new allocation restoring to the Court prospective control of procedure in actions at law that it had long held but never exercised, and that had been effectively withdrawn by the Conformity Act of $1872 .{ }^{17}$ In response to examples carefully chosen by the chief opponent of the bill, Senator Walsh, its supporters readily acknowledged that what might be deemed "practice and procedure" for other purposes was not within the bill's grant of power to the Supreme Court to make law prospectively-to act like a legislature. The most prominent of Senator Walsh's examples was limitations law. ${ }^{18}$

. In the hight of the Enabling Act's history, and even without it, the two dominant approaches to the Act-the Court's ${ }^{19}$ and Professor Ely's ${ }^{20}$-are both flawed as exercises in interpretation and in their capacity to serve us well im the future. In each case, preoccupation with Erie Railroad Co. v. Tompkins, ${ }^{21}$ its progeny and its baggage has been a major problem. Put another way, both the Court and Professor Ely failed to heed Walter Wheeler Cook's teaching. So, I believe, has Professor Carrington.

Froin 1941 until 1965 the Court was willing to acknowledge only those restrictions on its rulemaking power that the prevailing Erie jurisprudence set for its power to displace state law by federal judge-made rules (federal common law). ${ }^{22}$ In Hanna v. Plumer $^{23}$ the Court wisely

15. The primary actors were Thomas Shelton, Chief Justice William H. Taft, and Senator Albert Cummins. See Burbank, supra note 9, at 1050-98, 1188; see also Subrin, How Equity Conquered Common Law: The Federal Rules of Civil Procedure in Historical Perspective, 135 U. PA. L. REV. 909, 948-61 (1987).

16. See Burbank, supra note 9 , at 1106-07.

17. Act of June 1,1872 , ch. $255, \S \S 5-6,17$ Stat. 196, 197. See Burbank, supra note 9, at 1039 . 40.

18. See S. Rep. No. 1174, 69th Cong., 1st Sess. 9-16 (1926); Burbank, supra note 9, at 1083-89.

19. See, e.g., Burlington N.R.R. v. Woods, 480 U.S. 1 (1987); Hanna v. Plumer, 380 U.S. 460 (1965); Mississippi Publishing Corp. v. Murphree, 326 U.S. 438 (1946); Sibbach v. Wilson \& Co., 312 U.S. 1 (1941).

20. See Ely, The Irrepressible Myth of Erie, 87 HARV. L. Rev. 693 (1974).

21. 304 U.S. 64 (1938).

22. See Burbank, supra note 9, at 1032-33. Those decisions, however, "raised fears for' the integrity of the Federal Rules of Civil Procedure, many of which appeared vulnerable to the developing Erie jurisprudence." Id. at 1032 (footnote omitted).

23. 380 U.S. 460 (1965). 
disaggregated the "Erie problem." 24 We should remember that the "arguably procedural" 25 language adduced by Professor Carrington ${ }^{26}$ comes from Justice Harlan's solo concurrence and that, unlike Justice Harlan, the Court recognized two discrete sources of restrictions on court rulemaking. ${ }^{27}$ But the Court did fail to make clear how the Enabling Act's restrictions are functionally different from those imposed on Congress by the Constitution. Moreover-a possible explanation for that failure-the Court erroneously attributed both sets of restrictions to concerns about federalism. ${ }^{28}$

In revisiting the opinion in Hanna, Professor Ely clarified much, ${ }^{29}$ but his revised approach to the Enabling Act, ${ }^{30}$ although obviously more restrictive than the Court's, is not obviously an iniproveinent. His approach substitutes restrictions on rule application for restrictions on rule formulation, confining the Act to the protection of existing policy choices and, more importantly, to the protection of state law. ${ }^{31}$ It presents the additional problem of engaging the federal courts in the difficult and highly mamipulable business of ascertaining the pohicies aniınating particular rules of state law. ${ }^{32}$ For instance, we are usually left to our own devices in identifying the pohcies animating any given limitations provision. That those devices may be teleological is suggested by a comparison of conimentary suggesting that the foremost policy underlying statutes of limitations is protecting defendants from stale claims, with a

24. See Ely, supra note 20; Burbank, supra note 9, at 1033-35, 1164-76.

25. "Whereas the unadulterated outcome and forum-shopping tests may err too far toward honoring state rules, I submit that the Court's 'arguably procedural, ergo constitutional' test moves too fast and too far in the other direction." Hanna v. Plumer, 380 U.S. 460, 476 (1965) (Harlan, J., concurring).

26. Professor Carrington acknowledges the provenance and the mischief it may have caused. See Carrington, supra note 1, at 297; see also id. at $296 \mathrm{n} .87$ (quoting Chief Justice Warren in Hanna). Elsewhere, however, he seems to compound the mischief. See id. at 296-97; infra text acrompanying note 36 .

27. See Ely, supra note 20, at 720; Burbank, supra note 9, at 1034.

28. See Burbank, supra note 9, at 1034-35, 1187-88; Burbank, Rules and Discretion, supra note 13, at 699-700. For the continuing effects of this failure on academic commentary, see, e.g., Freer, Erie's Mid-Life Crisis, 63 Tulane L. Rev. 1087, 1104-05 (1989).

29. See Ely, supra note 20, at 693-718.

30. See id. at $718-40$.

31. See Burbank, supra note 9, at 1113-14, 1122-23, 1187-88; Burbank, Rules and Discretion, supra note 13, at 700. Although Professor Carrington alludes to Professor Ely's error in focusing exclusively on federalism to the exclusion of the underlying separation of powers issues, see Carrington, supra note 1 , at 298 , it is not clear that he has escaped preoccupation with the protection of existing policy choices (as opposed to allocation of policy choices). See id. at 290, 316-17.

32. See Burbank, supra note 9, at $1127 \&$ n.510, 1190-91. 
recent Fourth Circuit decision denying that such a policy animates statutes of limitations as opposed to statutes of repose. ${ }^{33}$

Contrary to a suggestion in Professor Carrington's article, ${ }^{34}$ the Court's 1987 opinion in Burlington Northern Railroad v. Woods, ${ }^{35}$ did not perpetuate Justice Harlan's caricature of the Court's opinion in Hanna. ${ }^{36}$ Nor, however, did it provide additional guidance on the Enabling Act's restrictions, as Professor Carrington seeins to think, ${ }^{37}$ one reason why another serious student of court rulemaking regards Burlington Northern as a disaster. ${ }^{38}$ Although Professor Carrington's discussion of the role of the Rules of Decision Act ${ }^{39}$ in the Court's opinions and of its proper role in resolving these questions is somewhat confusing, ${ }^{40}$ lie acknowledges that the Rules Enabling Act is concerned about allocation

33. Compare F. James \& G. Hazard, Civil Procedure $\$ 4.16$, at 218-19 (3d ed. 1985) (ordering "[p]rotection of a defendant from stale claims" and "[p]rotection of defendant from insecurity" ahead of "[p]rotection of courts from the burden of stale claims" in policy analysis) with Goad v. Celotex Corp., 831 F.2d 508, 511 (4th Cir. 1987) ("principal purpose of limiting statutes is the prevention of stale claims [from the perspective of courts], and . . . the repose of defendants is merely an incidental benefit"), cert. denied, 108 S. Ct. 2871 (1988); Burbank, supra note 9, at 1188 ("[N]either uniformity nor simplicity is well served by a rulemaking charter that sanctions Federal Rules valid in one state and not in another, here today, gone tomorrow.") (footnote omitted).

34. See Carrington, supra note 1, at 298-99.

35. 480 U.S. 1 (1987).

36. See supra note 25 .

37. See Carrington, supra note 1, at 298-99, 307-08 (contending that Burlington Northern added an "interpretive gloss" to the Act, barring Federal Rules having an effect on substantive rights that is more than "incidental"). The passage from Burlington Northern quoted by Professor Carrington, id. at 299 (quoting Burlington Northern, 480 U.S. at 5), adds nothing to Hanna, see Hanna, 380 U.S. at 464-65, or Mississippi Publishing Corp. v. Murphree, 326 U.S. 438, $445-46$ (1946), from which it was drawn. Thus, Burlington Northern reaffirmed the Court's toothless interpretation of the Enabling Act shortly before the Court admitted that some of its work product has "important," not "incidental," effects on substantive rights. See infra text accompanying note 189.

38. See Whitten, Erie and the Federal Rules: $A$ Review and Reappraisal after Burlington Northern Railroad v. Woods, 21 CREIGHTON L. REv. 1, 41-42 (1987).

39. 28 U.S.C. $\S 1652$ (1982) provides: "The laws of the several states, except where the Constitution or treaties of the United States or Acts of Congress otherwise require or provide, shall be regarded as rules of decision in civil actions in the courts of the United States, in cases where they apply."

40. See, e.g., Carrington, supra note 1, at 296 ("The Rules of Decision Act was clarified in Hanna v. Plumer."); id. at 297 ("Hanna surely secms to have gotten the Rules of Decision Act right."); id. at 299 (Burlington Northern involved "a challenge based on the Rules of Decision Act."). In fact, neither in dictum nor in holding did the Court in Hanna even cite the Rules of Decision Act. See Westen \& Lehman, Is There Life for Erie After the Death of Diversity?, 78 Мich. L. REv. 311, 371 n.181 (1980); Burbank, Interjurisdictional Preclusion, Full Faith and Credit and Federal Common Law: A General Approach, 71 CoRNELL L. REv. 733, 756, 787-88 (1986) (footnotes onitted) [hereinafter Burbank, Interjurisdictional Preclusion]. This proves only the influence of Professor Ely's gloss on that opinion. See Ely, supra note 20, at 707-18. From what appears in the Court's opinion in Burlington Northern, neither did the parties in that case mention the Rules of Decision Act. See 480 U.S. at 3. Here, appearances comport with reality: no party so much as cited the Rules of Decision Act. See, e.g., Brief of Petitioner at vii-viii, x-xi, Burlington N.R.R. v. Woods, 480 U.S. 1 (1987). 
of federal powers. ${ }^{41}$ The Court in Burlington Northern evinced no greater awareness of that fact than it had in Hanna. ${ }^{42}$

It cannot be easy for one who acknowledges that statutory restrictions were imposed for one purpose (allocation of federal powers) to deploy Supreme Court interpretations of those restrictions deriving froin a wholly different understanding (federalisin), ${ }^{43}$ which nnay explain Professor Carrington's schizophremic treatment of Hanna ${ }^{44}$ and his roseate view of Burlington Northern. 45 In any event, Walter Wheeler Cook would not have approved.

I believe that, under the original Enabling Act, the restrictions on court rulemaking sliould have been read to effect the purpose of allocating federal lawinaking power of the legislative type, not just to protect existimg law, and certainly not just to protect state law. ${ }^{46} \mathrm{~A}$ legal rule inay or inay not liave ascertainable purposes. But we know that soine legal rules, whitever policies supposedly animate them, have quite drainatic effects. Thus, I also believe that prospective federal lawmaking that necessarily and obviously involves policy choices with a predictable

More fundamentally, it is confusing or worse to term any challenge to the application of a pertinent Federal Rule (as to whicl there was doubt in Burlington Northern) "a challenge based on the Rules of Decision Act," whatever the ground of federal jurisdiction or the source of the law clained to apply in its stead. The part of the Court's opinion in Hanna that Professor Ely glossed under the Rules of Decision Act was dictum proceeding on the assuinption, contrary to the holding, that there was no pertinent Federal Rule of Civil Procedure. See Hanna, 380 U.S. at 466-72. The Constitution protects against overreaching by the federal government as against the states. The Enabling Act protects against overreaching by the Supreine Court acting prospectively as against Congress, and derivatively as against the states. "Valid Federal Rules displace state law under the Rules of Decision Act not because they are 'Acts of Congress' but because tliey are provided for by an act of Congress and one, inoreover, tliat was enacted after the Rules of Decision Act." Burbank, Interjurisdictional Preclusion, supra at 773; see also Ely, supra note 20, at 718. And again, this is true wliatever the ground of federal jurisdiction or the source of the law clained to apply. See Burbank, Interjurisdictional Preclusion, supra, at 753-62; infra text accoinpanying note 96. But see Carrington, supra note 1, at 295 (suggesting tliat Rules of Decision Act relevant only "in federal diversity litigation"); $i d$. at 316.

41. See Carrington, supra note 1, at 298.

42. See Burbank, Rules and Discretion, supra note 13, at 699-701; see also Oinni Capital Int'l v. Wolf \& Co., 484 U.S. 97, 111 (1987) (suggesting that the Court could proinulgate a valid Federal Rule of Civil Procedure "authorizing service [of process] on an alien in a federal question case"). But see Burbank, supra note 9, at 1172-73 n.673; Whitten, Separation of Powers Restrictions on Judicial Rulemaking: A Case Study of Federal Rule 4, 40 ME. L. REv. 41 (1988).

43. See Burbank, Rules and Discretion, supra note 13, at 701.

44. Compare Carrington, supra note 1, at 297-99 (Hanna's "false step") with id. at 316 ("Had Hanna becn decided otlerwise, one might be teinpted to suggest, as a problematic case . . ..") (footnote omitted); id. at 319 ("Hanna gave an affirmative answer to botll questions [set forth infra note 71] in an action to enforce a state-created right.") (footnote omitted); id. at 320 ("Wonder as we may, the fact is tliat Hanna did establislı Rule 4 as a source of limitations law."). See also infra text accompanying note 88 .

45. See supra text accompanying notes 35-38.

46. See, e.g., Burbank, supra note 9, at 1106-14, 1122-25, 1187-88. 
and identifiable impact on rights claimed under substantive law is properly the province of Congress. ${ }^{47}$ Both the prospective formulation of a limitations period-two years or four years?-and the prospective formulation of a rule to determine when that period ceases to run in response to litigation activity-filing or service?-involve policy choices of this type. They are not, contrary to Professor Carrington's view, suitable subjects for court rules. ${ }^{48}$ Neither is it appropriate for a court rule, under the guise of "relation back," to permit a new party to be haled into court beyond the period of the apphicable limitations period, at least when there is no relationship between the original and new parties. ${ }^{49}$

The 1938 relation back provision in Rule 15(c) is, as Professor Carrington suggests, more difficult to analyze. ${ }^{50}$ Mindful of the inattention to, confusion about, and outright dissembling regarding questions of power by members of the original Advisory Committee, ${ }^{51}$ I cannot acquiesce in any inference of validity from the mere existence of that provision. ${ }^{52}$ Moreover, we should recall that Congress was assured in 1938 that the Court would be "zealous to correct [a] mistake, if any has been

47. See id. at 1127-31, 1189-93.

48. See id. at 1128. Professor Carrington does not advocate a view of the Enabling Act that would permit the Court to create a limitations period by court rule. But he does argue that the second type of rule (filing or service?) is valid. See Carrington, supra note 1, at 321.

49. See FED. R. CIV. P. 15(c):

Whenever the claim or defense asserted in the amended pleading arose out of the conduct, transaction, or oceurrence set forth or attempted to be set forth in the original pleading, the amendment relates back to the date of the original pleading. An amendment changing the party against whom a claim is asserted relates back if the foregoing provision is satisfied and, within the period provided by law for commencing the action against the party to be brought in by amendment, that party (1) has received such notice of the institution of the action that the party will not be prejudiced in maintaining a defense on the merits, and (2) knew or should have known that, but for a mistake concerning the identity of the proper party, the action would have been brought against the party.

The delivery or mailing of process to the United States Attorney, or the United States Attorney's designee, or the Attorney General of the United States, or an agency or officer who would have been a proper defendant if named, satisfies the requirement of clauses (1) and (2) hereof with respect to the United States or any agency or officer thereof to be brought into the action as a defendant.

See also Carrington, supra note 1, at 312.

50. See Carrington, supra note 1, at 310-11. It is not true, however, that the original rule "could have no other referent," $i d$. at 310 , than limitations law. See 6 C. Wright \& A. Miller, Federal Practice AND Procedure § 1497, at 492 (1971) ("subject matter jurisdiction, venue or personal jurisdiction").

51. See Burbank, supra note 9, at 1132-37.

52. But see Carrington, supra note 1, at 310. Professor Carrington's citation of my work in support of the proposition that "even in 1938, it was clear enough to rulemakers that some rules bearing on limitations law would fall within the authority conferred by the first sentenee of the 1934 Act," id. (footnote omitted), is mystifying. The technique I discussed in the article he cites, see id. at 310 n.182-reverse incorporation-involves the use of a Federal Rule by a court making common law. See Burbank, supra note 9, at 1158-63; infra text accompanying note 64. More generally, as observed in the text and illustrated by one of the quotations that begins this Comment, the rulemakers had no coherent concept of their authority. 
made."53 Such zeal! ${ }^{54}$ Nor am I content to rest with then-Professor Kaplan's observation in discussing Rule 25 on substitution of parties, that the Rule deals with "an incident of an already existing action." 55 Given that fact, however, and given that the Court unquestionably had the power to banish both fact pleading and the concept of a cause of action froin federal practice, ${ }^{56}$ and given that decisions discovering a new cause of action in an amended pleading were hardly predictable, ${ }^{57} \mathrm{I}$ will not claim overreaching.

Implicit in what I have said above, and explicit in what I have previously written about the Enabling Act, is the view that when the Supreme Court makes law through supervisory court rules, it is engaged in an enterprise that, both practically and normatively, is different in important respects from the enterprise in which the Court, or any federal court, is engaged when it makes federal common law. ${ }^{58}$ Incorporation of preexisting federal common law in court rules is, on the other hand, both understandable and easy enough to defend agamst a techirical attack so long as the common law rule is valid in both federal question and state law diversity cases. When the common law rule could not validly be apphed in a state law diversity case because of Erie and its progeny, the incorporation teclinique is a bootstrap operation..$^{59}$ Rule 23.1 on derivative actions provides a good example of this. ${ }^{60}$

53. Letter from Edgar B. Tolman to the Hon. J.C. O'Mahoney, the Hon. W.H. King, the Hon. E.R. Benke, and the Hon. W.R. Austin (May 26, 1938), reprinted in Hearings on S.J. Res. 281 Before a Subcomm. of the Senate Comm. on the Judiciary, 75th Cong., 3d Sess., pt. 1, app. 69, 72 (1938).

54. See Burbank, supra note 9, at 1179:

With the exception of cases in which it has read Federal Rules not to apply, however, the main thing the Supreme Court has been zealous about in considering challenges to their validity has been taking cover behind the process enployed prior to their effeetive date, particnlarly that part of it permitting congressional review. Such has been the rulemaking renvoi.

See also Burbank, Rules and Discretion, supra note 13, at 700 \& n.53.

55. Kaplan, Amendments of the Federal Rules of Civil Procedure, 1961-63(I1), 77 HARv. L. REV. 801, 810 (1964); see Burbank, supra note 9, at 1156 \& n.607.

56. See Carrington, supra note 1 , at 310 .

57. See C. Clark, Code Pleading 729-34 (2d ed. 1947); R. Millar, Civil Procedure of THE Trial Court in Historical Perspective 184-85 (1952).

58. See, e.g., Burbank, supra note 9, at 1147-57, 1192-93; Burbank, Rules and Discretion, supra note 13 , at $698-713$.

59. See Burbank, supra note 9, at 1147-55.

60. FED. R. Crv. P. 23.1 provides:

In a derivative action bronght by one or more shareholders or members to enforce a right of a corporation or of an unincorporated association, the corporation or association having failed to enforce a right which may properly be asserted by it, the complaint shall be verified and shall allege (1) that the plaintiff was a shareholder or member at the time of the transaction of which the plaintiff complains or that the plaintiff's share or membership thereafter devolved on the plaintiff by operation of law, and (2) that the action is not a collusive one to confer jurisdiction on a court of the United States which it would not otherwise have. The complaint shall also allege with particularity the efforts, if any, made by the plaintiff to obtain the action the plaintiff desires from the directors or comparable 
Professor Carrington may be thought to suggest that criticism of the Court for relying on Rule 3 to provide the rule for stopping a borrowed federal period of limitations in West $v$. Conrail ${ }^{61}$ - a federal question case-is an academic exercise, ${ }^{62}$ although his treatment of that decision is also schizophremic. ${ }^{63}$ One alternative approach to the problem, and one means of rationalizing the result in West, would involve what $I$ have called reverse incorporation: the use of an existing court rule in its incorporated substantive aspects as federal common law. ${ }^{64}$ I harbor no serious doubts about the Court's power to fashion a uniform tolling rule for the apphicable limitations period in most federal question cases. ${ }^{65}$ The problem with reverse incorporation here is not only that Rule 3 does not reflect the accumulated experience of case law, i.e., "preexisting federal common law," and thus is not an example of incorporation; it is also that, were the Court to proceed on a case-by-case or statute-by-statute basis, it would be unlikely to find that filing is the appropriate tolling

authority and, if necessary, from the shareholders or members, and the reasons for the plaintiff's failure to obtain the action or for not making the effort. The derivative action may not be maintained if it appears that the plaintiff does not fairly and adequately represent the interests of the shareholders or members similarly situated in enforcing the right of the corporation or association. The action shall not be dismissed or compromised without the approval of the court, and notice of the proposed dismissal or coinpromise shall be given to shareholders or members in such manner as the court directs.

See Burbank, supra note 9, at 1154-55.

61. 481 U.S. 35 (1987).

62. See Burbank, Rules and Discretion, supra notc 13, at 699; Carrington, supra note 1, at 314 15. Yet he now goes on to term "this interpretation of the decision [i.e., resort to Rule 3 as a gap. filler] doubtful." Id. at 315 .

63. See supra note 44 and accounpanying text. Having acknowledged that the Court "recog. nized the tolling effect of Rule 3 without questioning whether such a tolling rule is authorized by the Rules Enabling Act," Carrington, supra note 1, at 314, Professor Carrington asserts that "West ... leaves little doubt that separation of powers considerations arc . . . no impediment to the creation by court rule of a provision for commencement-by-filing." Id. at 316.

64. See Burbank, supra note 9, at 1158-63.

65. The notable exception is cases governed by 42 U.S.C. $\S 1988$, which states:

The jurisdiction in civil and criminal matters conferred on the district courts by the provisions of this Title, and of Title "CIVIL RIGHTS," and of Title "CRIMES," for the protection of all persons in the United States in their civil rights, and for their vindication, shall be exercised and enforced in conformity with the laws of the United States, so far as such laws are suitable to carry the same into effect; but in all cases where they are not adapted to the object, or are deficient in the provisions necessary to furnish suitable remedies and punish offenses against law, the common law, as modified and changed by the constitution and statutes of the State wherein the court having jurisdiction of such civil or criminal cause is held, so far as the same is not inconsistent with the Constitution and laws of the United States, shall be extended to and govern the said courts in the trial and disposition of the cause, and, if it is of a criminal nature, in the infliction of punishment on the party found guilty. In any action or proceeding to enforce a provision of sections 1981, 1982, 1983, 1985, and 1986 of this title, title IX of Public Law 92-318 or title VI of the Civil Rights Act of 1964, the court, in its discretion, may allow the prevailing party, other than the United States, a reasonable attorney's fee as part of the costs.

42 U.S.C. $\$ 1988$ (1982). 
event for every federal and borrowed federal or state statute it encountered.66 At the least, the experience might cause the Court to doubt whether the benefits of a trans-substantive tolling rule were worth the costs, including the costs to litigants of multiple sources of limitations law, ${ }^{67}$ particularly when the Court realized that Rule 3 cannot in any event provide the solution for federal question cases brought in state court. 68

Even if the Court were to announce a trans-substantive federal tolling rule for federal question cases in state court that is identical to Rule 3 , it probably would not be able to avoid problems created by another mistake it has made, first in Hanna and again in West. That mistake is the subject of comment by Professor Carrington and prompts his inquiries regarding Rule 4. I refer to the highly artificial parsing of the Massachusetts statute in Hanna into limitations provisions and "notice" provisions, ${ }^{69}$ and a similar sleight of hand in West. ${ }^{70}$ First, to address two of Professor Carrington's questions: ${ }^{71}$ the Court in Hanna did not assert, and I believe that it would have demed, that it was using Rule 4 to toll (i.e., stop the running of) a statute of limitations im a diversity case. ${ }^{72}$ To reframe and answer another of his questions, ${ }^{73}$ the reason for this technique in Hanna seems clear. By invoking a "threat to the goal of uniformity of federal procedure" 74 that did not exist-none of the state

66. This analysis is developed in greater detail in Burbank, Rules and Discretion, supra note 13, at 707-09.

67. Compare Carrington, supra note 1, at 315 (trans-substantive rule is "less complex") with Burbank, Rules and Discretion, supra note 13, at 709 ("[T] he resulting inelange of legal sources might seem more complicated, a perception that could impose costs of its own."). See also id. at 707-09 (trans-substantive rules distort substantive law).

68. See FED. R. Civ. P. 1; Burbank, Rules and Discretion, supra note 13, at 710-12.

69. See Hanna v. Plumer, 380 U.S. 460, $462-63$ n.1 (1965); Burbank, supra note 9, at 1173-76; Burbank, Rules and Discretion, supra note 13, at 707.

70. See West v. Conrail, 481 U.S. 35, 38-39, 40 n.7 (1987); Burbank, Rules and Discretion, supra note 13, at 707-08.

71. "Should this rule (Rule 4) be given effect as a prescription of the conduct required of the plaintiff-namely the means by which notice is given to the defendant-to make a timely commeucement of an action? If so, is it a valid exercise of the rulemaking power?" Carrington, supra note 1, at 319 ; see supra note 44.

72. See Burbank, supra note 9, at 1173-76. But see Carrington, supra note 1, at 319 ("Hanna gave an affirmative answer to both questions in an action to enforce a state-created right"); id. at 320 ("Hanna did establish Rule 4 as a source of limitations law.").

73. "One may still wonder why the Court did not read Rule 4 more narrowly so that it applies only to resolve questions of the sufficiency of notice to the defendant and the power of the court over her person ...." Carrington, supra note 1, at 319. This, of course, is not a wonder if one takes the view that the Court in Hanna would have denied the broad reading of Rule 4 imputed to it by Professor Carrington. See supra text accompanying note 72. The question rather is why the Court wrenched the Massachusetts statute out of shape.

74. Hanna v. Plumer, 380 U.S. 460,463 (1965). 
statutes cited in support of the threat involved service or "notice" in connection with a state limitations provision-"and by dissecting the Massachusetts statute with a scalpel, the Court in Hanna provided itself with an occasion to circumvent the Act's limitations in the interest of clarifying the confusion wrought by its"75 prior decisions.

The quest for uniformity, however simple-minded, also serves as an adequate explanation of the Court's invocation of Rule $4(j)$ in West ${ }^{76}$ as a backstop to Rule 3, a feat that turned a six-inonth period into a tenmonth period. ${ }^{77}$ In West, however, the manipulation was even more egregious than in Hanna because Rule 4(j) is a statute, ${ }^{78}$ and its legislative history inakes crystal clear that, contrary to Professor Carrington's

75. Burbank, supra note 9 , at 1176 .

76.' FED. R. CIV. P. 4(j) provides:

If a service of the summons and complaint is not made upon a defendant within 120 days after the filing of the complaint and the party on whose behalf such service was required cannot show good cause why such service was not made within that period, the action shall be dismissed as to that defendant without prejudice upon the court's own initiative with notice to such party or upon motion. This subdivision shall not apply to service in a foreign country pursuant to subdivision (i) of this rule.

77. See West v. Conrail, 481 U.S. 35, 37, 40 n.7 (1987); Burbank, Rules and Discretion, supra note 13 , at 707-09.

78. Rule 4(j) was added by Pub. L. No. 97-462, $\S 2,96$ Stat. 2527,2528 (1983). 
confident assertions, ${ }^{79}$ it was not intended to function as limitations law. ${ }^{80}$

79. Carrington, supra note 1, at 320-21 (footnotes omitted) (emphasis added):

Wonder as we may, the fact is that Hanna did establish Rule 4 as a source of limitations law. The Court seemed to say with respect to limitations matters, that the Rules Enabling Act trumps the Rules of Decision Act wherever both are played on the same trick even with respect to provisions having no necessary application. As others have remarked, this position is inconsistent with the approach, although not the holdings, in Ragan and Walker. But such remarks only emphasize the reality that Rule 4 is now a provision of federal limitations law as well as a prescription of the method by which defendants are notified of actions filed against them. Perhaps for additional emphasis, Congress in 1982 also added subdivision (j) to Rule 4, a provision with potentially substantial consequences as limitations law.

If there could be any doubt about Rule 4's validity as himitations law, the doubt was erased in 1982 by the adoption of Rule 4 as a statute. Under this circumstance, no separation of powers issue can reinain.

Despite this certainty, it may be useful to inquire....

See also id. at $320 \mathrm{n} .247$ (Rule 4(j) "can be even inore readily construed as an inplied tolling provision than can those provisions of Rule 4 which originated with court rulemaking.").

This passage is remarkable for a number of reasons other than its assertions about Rule 4(j). See infra note 80. As noted above, Hanna did not "establish Rule 4 as a source of limitations law." See supra text accoinpanying note 72 . Even if reasonable people can disagree about what the Court thought it was doing in Hanna, once it is recognized that the Court in that case proceeded from an erroneous premise about the purpose of the procedure/substance dichotomy, it is hard to agree that the decision "establish[es]" anything about the Enabling Act. See supra text accoinpanying notes 2345. Finally, the suggestion that Congress may have added Rule 4(j) "for additional emphasis" and the notion that "any doubt about Rule 4's validity as himitations law ... was erased in 1982 [sic] by the adoption of Rule $\mathbf{4}$ as a statute," are both irrelevant and wrong. Apart from the evidence in the legislative history that Rule 4(j) was not intended to serve as a "tolling rule," see infra note 80 and accompanying text, the legislation of which Rule 4(j) was a part did not include amendments to the provision at issue in Hanna, Rule 4(d)(1). See Hanna, 380 U.S. at 461-66, 474; Pub. L. No. 97-462, 96 Stat. 2527, 2528 (1983). In other words, not all of Rule 4 was adopted as a statute in 1983. And even if it had been, what does that prove about the Enabling Act?

80. In the absence of any committee reports, the explanation of the bill that was enacted given by its sponsor, Representative Edwards, is the best evidence on this point. With reference to Rule 4(j) he explained:

Like proposed subseetion (j), H.R. 7154 provides that a disınissal for failure to serve within 120 days shall be "without prejudice". Proposed subsection (j) was criticized by soine for ambiguity because, it was argued, neither the text of subsection ( $j$ ) nor the Advisory Coinmittee Note indicated whether a dismissal without prejudice would toll a statute of himitation. See House Report 97-662, at 3-4 (1982). The problen would arise when a plaintiff files the complaint within the applicable statute of limitation period but does not effect service within 120 days. If the statute of hmitation period expires during that period, and if the plaintiff's action is dismissed "without prejudice," can the plaintiff refile the complaint and inaintain the action? The answer depends upon how the statute of limitation is tolled.

If the law provides that the statute of linitation is tolled by filing and service of the complaint, then a dismissal under H.R. 7154 for failure to serve within the 120 days would, by the terms of the law controlling the tolling, bar the plaintiff froun later maimtaining the cause of action. If the law provides that the statute of limitation is tolled by filing alone, then the statns of the plaintiffs's cause of action turns upon the plaintiff's diligence. If the plaintiff has not been diligent, the court will dismiss the complaint for failure to serve within 120 days, and the plaintiff will be barred from later inaintaining the cause of action because the statute of limitation has run. A dismissal without prejudice does not confer upon the plaintiff any rights that the plaintiff does not otherwise possess and leaves a plaintiff whose action has been dismissed in the same position as if the action had never been filed. If, on the other hand, the plaintiff has made rcasonable efforts to effect service, then the plaintiff can move under Rule $6(\mathrm{~b})$ to enlarge the time within which to serve or can 
What then are the problems I refer to that would attend a transsubstantive federal tolling rule for federal question cases in state court? As a result of West, real uniformity as to limitations im federal question cases can come about only if the Court is willing to impose on state courts common law rules that are identical, not just to Rule 3 , but also to Rule 4(j). ${ }^{81}$ As one who, in the context of preclusion law, has advocated clearer thinking about federal common law in state courts, ${ }^{82} \mathrm{I}$ await the denouement with some trepidation. Federal limitations law is a mess, one that deserves sustained congressional attention. ${ }^{83}$

Whatever the difficulties with reverse incorporation, imputing that process (or simply sloppy shorthand for federal common law) to the Court in West would at least permit the decision to co-exist with the Court's earlier decision in Walker v. Armco Steel Co., a diversity state law case. ${ }^{84}$ In contrast, taking West at face value as a direct application of Rule 3 rather than an expression of federal common law incorporating Rule 3, the two cases can be reconciled only if Rule 3 is accorded two "plain meaning[s]," "85 _one for diversity state law cases and another for

oppose dismissal for failure to serve. A court would undoubtedly permit such a plaintiff additional time within which to effect service. Thus, a diligent plaintiff can preserve the cause of action. This result is consistent with the policy behind the time limit for service and with statutes of limitation, both of which are designed to encourage prompt inovement of civil actions in the federal courts.

128 CoNG. REC. 30,931-32 (1982) (footnotes onitted) (emphasis added).

The footnote omitted at the end of the first quoted paragraph imparts special irony to the use Professor Carrington makes of Rule 4(j), as well as to the assertions he makes about Rule 4. See supra note 79.

The law governing the tolling of a statute of limitation depends upon the type of civil action involved. In a diversity action, state law governs tolling. Walker v. Armco Steel Corp., 446 U.S. 740, 750-51 (1980). In Walker, plaintiff had filed his coinplaint and thereby commenced the action under rule 3 of the Federal Rules of Civil Procedure within the statutory period. He did not, however, serve the sumınons and coinplaint until after the statutory period had run. The Court held that state law (which required both filing and service within the statutory period) governed, barring plaintiff's action.

In the federal question action, the courts of appeals have generally held that Rule 3 governs, so that the filing of the complaint tolls a statute of limitation. ... The continued validity of this line of cases, however, must be questioned in light of the Walker case, even though the Court in that case expressly reserved judgment about federal question actions, see Walker v. Armco Steel Corp., 446 U.S. 741, [sic] 751 n.11 (1980).

128 CONG. REC. 30,931-32 n.12 (1982) (emphasis added).

81. See Burbank, Rules and Discretion, supra note 13, at 712.

82. See Burbank, Interjurisdictional Preclusion, supra note 40, at 805-10; Burbank, Rules and Discretion, supra note 13 , at $710-12$.

83. See Burbank, Rules and Discretion, supra note 13, at 712-13; Lewellen v. Morley, 875 F.2d 118, 121 (7th Cir. 1989); White, Some Current Debates, 73 Judicature 155, 158 (1989).

There is reason to hope that the Federal Courts Study Committee established by Title I of Pub.

L. No. 100-702, 102 Stat. 4642, 4644 (1988), will make recommendations to clean up the iness.

84. 446 U.S. 740 (1980).

85. Having observed that the "Federal Rules should be given their plain meaning," 446 U.S. at 750 n.9, the Court in Walker found "no indication that the Rule was intended to toll a state statute of limitations." Id. at 750 (footnote omitted). See Burbank, Rules and Discretion, supra note 13, at 701-02; Carrington, supra note 1, at 315. 
federal question cases. That approach, however, would violate Professor Carrington's principle of generalism. ${ }^{86}$ Whether for that reason, ${ }^{87}$ or to have the benefit of the supposed legal results in Hanna and West, however incoherent, ${ }^{88}$ Professor Carrington asserts that Walker is "simply an anomaly." 89 Both this assertion and his subsequent analysis of the limitations implications of Rule $23^{90}$ demonstrate that Professor Carrington has paid insufficient attention to the differences between federal court rulemaking and federal common law. As in his readimg of Rule 4, he has "see[n] in the Federal Rules of Civil Procedure support for [limitations] rules that is not there." 91

Rule 23 does not provide a rule for tolling the applicable limitations period, state or federal, in a class action brought in federal court, 92 and American Pipe \& Construction Co. v. Utah, ${ }^{93}$ does not suggest otherwise. In that case, the Supreme Court was inaking federal common law. Both the governing substantive law and the applicable limitations period were federal. ${ }^{94}$ As there could be no doubt under either the Court's approach to federal common law ${ }^{95}$ or an approach that takes the Rules of Decision Act seriously, ${ }^{96}$ that the tolling rule should be uniforn, ${ }^{97}$ in creating it the Court had "the power to fashion a [rule] that [was] fully adequate in hight of all of the policies and interests that a common law court would consider in inaking law to govern the matter."98 Even though Rule 23 does not and could not validly provide a tolling rule, in devising such a rule "not inconsistent with the legislative purpose," 99 the Court was not required to ignore the policies exogenous to limitations that animate

86. See Carrington, supra note 1, at 302-05. For criticisms of Professor Carrington's views on this subject, see Burbank, Transformation, supra note 13, at 1935-37, 1939-41. See also infra text accompanying notes 196, 211-13.

87. See Carrington, supra note 1, at 315; see also infra text accompanying note 153.

88. See supra text accompanying notes 34-45; supra note 79.

89. Carrington, supra note 1 , at 316 .

90. Id. at 317-18.

91. Burbank, Interjurisdictional Preclusion, supra note 40, at 771 (footnote omitted).

92. See FED. R. CIV. P. 23.

93. 414 U.S. 538 (1974).

94. See id. at 541-42.

95. See Burbank, Interjurisdictional Preclusion, supra note 40, at 755-58.

96. See id. at 758-62.

97. See id. at 773-76.

98. Id. at 771 (footnote omitted).

99. American Pipe \& Const. Co. v. Utah, 414 U.S. 538, 559 (1974); see also id. at 557-58 \& n.29. 
Rule 23,100 including in particular the policy against "multiplicity of activity." 101 The Court was not persuaded by the attempt of the petitioners in American Pipe to measure the Court's power to make law "by judicial decision" according to its power to make law by "court rule."102 Nor should we be persuaded by Professor Carrington's description of American Pipe as involving "the use of Rule 23 to toll the statute during the pendency of the class suit."103

Similarly, in Chardon v. Fumero Soto ${ }^{104}$ the Court did not, as Professor Carrington would have it, apply Puerto Rican limitations law "on the authority of Rule 23." 10 s The Court was directed to apply state law by 42 U.S.C. $\S 1988,{ }^{106}$ which I have previously described as "a statute similar to the Rules of Decision Act but more narrowly focused and hence not as easy to ignore or wish away," 107 a description that now appears to be optimistic. Had the Puerto Rican tolling provision been less generous, creating a risk of a multiplicity of actions to avoid a time bar, the Court might have been required to determine whether it should yield because it was "inconsistent with the . . . laws of the United States," 108 of which Rule 23, for these purposes, is one. ${ }^{109}$ No more than

100. Burbank, Interjurisdictional Preclusion, supra note 40, at 773-74 (footnotes omitted): Federal Rules of Civil Procedure are not, however, irrelevant. The Rules Enabling Act authorizes the Supreme Court to promulgate "general"-that is, uniform-Federal Rules of practice and procedure. ... Valid Federal Rules displace state law under the Rules of Decision Act not because they are "Acts of Congress" but because they are provided for by an act of Congress and one, moreover, that was enacted after the Rules of Decision Act. In authorizing the Court to promulgate Federal Rules, Congress must have contemplated that the federal courts would interpret thein, fill their interstices, and, when necessary, ensure that their provisions were not frustrated by other legal rules. That does not inean that the federal courts are free to create uniform federal decisional law or displace particular state law rules in areas untouched by the Federal Rules. It does mean, however, that when the Supreme Court has exercised the power delegated by Congress to prescribe uniform Federal Rules, we should regard those Rules, if valid, as if they were acts of Congress. In effect, they are assimilated to the Enabling Act for purposes of the Rules of Decision Act. Because Federal Rules cannot validly provide for the creation of federal common lawRule 83 in that aspect is invalid-they are sourees of power ouly if, fairly read, they may be said to require it.

Federal Rules of Civil Procedure can thus serve as sources of federal common law, not only by leaving interstices to be filled but also by expressing policies that are pertinent in areas not covered by the Rules. Even when legal regulation in a certain area is forbidden to the Rules, the policies underlying valid Rules may help to shape valid federal common law.

101. American Pipe, 414 U.S. at 551.

102. Id. at $\mathbf{5 5 6}$ (footnote omitted). In the footnote to this description of the petitioners' argument, the Court quoted froin the Enabling Act. Id. at 556 n.26.

103. Carrington, supra note 1 , at 318. See infra note 129.

104. 462 U.S. 650 (1983).

105. Carrington, supra note 1, at 318 ; see also id. ("Rule 23 . . . used as a source of limitations law . . . to invoke the tolling provision of Puerto Rican law").

106. 42 U.S.C. $\S 1988$ (1982). For the text of $\S 1988$, see supra note 65 .

107. Burbank, Rules and Discretion, supra note 13, at 705.

108. See 42 U.S.C. $\$ 1988$.

109. See supra note 100 and accompanying text. 
Rule 4 does Rule 23 itself advance Professor Carrington's thesis regarding the original Enabling Act; unlike Hanna v. Plumer, the Court's decisions interpreting Rule 23 do not advance that thesis at all. ${ }^{110}$

The "original Enabling Act" no longer exists, however, having been replaced by title IV of the Judicial Inprovements and Access to Justice Act. ${ }^{111}$ Professor Carrington celebrates one decision inade by Congress in overhauling the statutory provisions that govern supervisory and local court rulemaking - the decision to retain the supersession clause. ${ }^{112}$ Indeed, he supports his defense of that provision by reference to the legislative history. ${ }^{113} \mathrm{He}$ does not, however, discuss other parts of the 1988 legislation or its legislative history that may have implications for the questions he addresses, rendering irrelevant both the "functional analysis [and] ... half century of experience with rules touching on himitations issues" 114 on which he relies. Perhaps that is because the words of the basic grant of rulemaking authority are similar, ${ }^{115}$ and Professor

110. Put another way, Professor Carrington and I agree that "[i]t would have been harsh gamesmanship in either case to bar the imdividual claimants who may have relied on the filing of the class suit to proteet their interests and nothing in the Rules Enabling Act could have required such results." Carrington, supra note 1, at 318-19. In both cases, however, the Enabling Act was irrelevant: in American Pipe because the Court was fashioning federal coinunon law, and in Chardon because it was following the mandate of section 1988.

111. Pub. L. No. 100-702, 102 Stat. 4642, 4648-52 (1988).

112. See Carrington, supra note 1 , at 321-26.

113. See id. at 324 n. 260 .

114. Id. at 321 .

115. Prior to its amendment in 1988 , section 2072 provided:

The Supreme Court shall have the power to prescribe by general rules, the forms of process, writs, pleadings, and motions, and the practice and procedure of the district courts and courts of appeals of the United States in civil actions, including adiniralty and maritine cases, and appeals therein, and the practice and procedure in proceedings for the review by the courts of appeals of decisions of the Tax Court of the United States and for the judicial review or enforcement of orders of administrative agencies, boards, commissions, and officers.

Such rules shall not abridge, enlarge or modify any substantive right and shall preserve the right of trial by jury as at common law and as declared by the Seventh Amendinent to the Constitution.

Such rules shall not take effect until they have been reported to Congress by the Chief Justice at or after the beginning of a regular session thereof but not later than the first day of May, and until the expiration of ninety days after they have been thus reported.

All laws in conflict with such rules shall be of no further force or effect after such rules have taken effect. Nothing in this title, anything therein to the contrury notwithstanding, shall in any way limit, supersede, or repeal any such rules heretofore prescribed by the Supreme Court.

28 U.S.C. $\S 2072$ (1982) (einphasis added).

For the text following amendment, see supra note 5 . 
Carrington neglected the possibility that their interpretation might be informed by the legislative history. ${ }^{116}$ Ignorance or neglect of the legislative history of the Rules Enabling Act of 1934 was pandemic. ${ }^{117}$

Alternatively, Professor Carrington may not agree that the legislative history of the 1988 Act in question is relevant or helpful. Let us first see what hight, if any, that history sheds on the interpretation of its limitations on court rulemaking. We can then consider questions of relevance and weight and thus determine whether the gnest list for Professor Carrington's party should be expanded.

The 1988 legislation revising the arrangennents for federal court ruleinaking was boru in the House of Representatives. As described in the 1988 House Judiciary Committee Report:

These provisions have evolved from a review of the operation of the current Rules Enabling Acts that dates back to activities of the Subcommittee on Courts, Civil Liberties, and the Administration of Justice in the 98th and 99th Congresses. Title I of the bill before the House is substantially identical to H.R. 1507, a bill that, witl minor changes, is identical to a bill (H.R. 3550) passed unanimously by the House in the 99th Congress. The Committee's Report on last Congresses' bill applies to the provisions of title I, except as noted below. Title I is also virtually identical with title II of H.R. 2182 that passed the House during the first session of the 100th Congress. ${ }^{118}$

With the exception of the language regarding supersession, the changes to section 2072 proposed in the Senate bill, which was enacted, were identical to those proposed in the House bill, ${ }^{119}$ their source. ${ }^{120}$

116. Yet, Professor Carrington has elsewhere referred to the very legislative documeut that is discussed herein. See Carrington, Bogy, supra note 3, at 2073 n.34, 2086 n.108.

117. See Burbank, supra note 9, at 1023-24. Particularly since Professor Carrington is not in this group, see, e.g., Carrington, supra note 1, at 288, 308-09, his assertion that the 1934 Act's "legislative history is limited," $i d$. at 282-83, is surprising. See Burbank, supra note 8, at 432-33 ("[t]here is an uncommonly rich legislative history" accompanying the Enabling Act).

118. H.R. REP. No. 889, 100th Cong., 2d Sess. 26 (1988) (footnotes omitted) (emphasis added); see id. at $27-29$.

119. Compare S. 1482, 100th Cong., 2d Sess. $§ 401(a), 134$ CoNG. REc. S16,286 (daily ed. Oct. 14,1988 ) (proposed Senate amendments to $\$ 2072$ ) with H.R. 4807, 100th Cong., 2d Sess., $\$ 101(a)$, 134 CoNG. Rec. $H 7444$ (daily ed. Sept. 13, 1988) (proposed House amendments to $\S 2072$ ). See also 134 CONG. REC. H10,432 (daily ed. Oct. 19, 1988).

120. See infra text accompanying note 132 . 
With the same exception, the changes were also identical to those proposed in H.R. 3550, ${ }^{121}$ which was explained in a House Judiciary Committee Report ${ }^{122}$ that was specifically imcorporated by reference in the Report on the 1988 House bill. ${ }^{123}$

The House Judiciary Committee Report on H.R. 3550 stated that the bill "improves the rulemaking process because it . . . clarifies the limitations on national or supervisory rulemaking by the Supreme Court." "124 The Report contains a lengthy account of "[c]riticism of the rulemaking process," 125 including specific criticisms of the 1983 and 1984 proposals to anend Federal Rule of Civil Procedure 68 as ultra vires. ${ }^{126}$ More important, the Report's section-by-section analysis elaborates the bill's limitations on the rulemaking power:

Proposed section 2072 contains limitations on the rulemaking power, careful observance of which is essential in the future if problems of the sort that prompted this legislation are not to recur.

The most important of these limitations is that rules promulgated by the Supreme Court for lower federal courts (supervisory court rules) be "rules of practice and procedure" that do not "abridge, enlarge, or modify any substantive right." The language is derived from current law. As interpreted by the Court, however, the language has little if any determinative content. As a result, the rules enabling acts have failed to provide guidance to the rulemakers or to Congress in considering the validity of proposed rules.

It appears that, as used in the Rules Enabling Act of 1934, the restriction regarding substantive rights was intended to emphasize some of the limitations on the delegation of prospective lawmaking power thought to inhere in the notion of court rules of "practice and procedure." Because there is no shared conception of such limitations today, the Committee believes that it must take some care in statimg its views on the scope of Congress' delegation under proposed section 2072.

First, it is not the purpose of proposed section 2072 merely to restate whatever may be the constitutional restramts on the exercise of Congress' lawmaking power as against that of the States or on the delegation of Congress' lawmaking power to the Supreine Court. Rather, proposed section 2072 contains independent limitations on supervisory court rulemaking, which Congress has the power to impose and which have the effect of delegating only a portion of Congress' power.

121. Compare S. 1482, 100th Cong., 2d Sess., $\S 401$ (a), 134 CoNG. REC. S16,286 (daily ed. Oct. 14,1988 ) with H.R. 3550, 99th Cong., 1st Sess. § 2(a) (1985), reprinted in H.R. REP. No. 422, 99th Cong., 1st Sess. 1-4 (1985).

122. H.R. REP. No. 422, 99th Cong., 1st Sess. (1985).

123. See supra text accompanying note 118; H.R. REP. No. 889, 100th Cong., 2 d Sess. 29 (1988) (referring to H.R. REP. No. 422, 99th Cong., lst Sess. (1985) in section-by-section analysis).

124. H.R. REP. No. 422 , 99th Cong., 1st Sess. 5 (1985).

125. Id. at 12-14.

126. See id. at 13 . 
Second, Congress' lawmaking power regarding matters of practice and procedure extends to all litigation in the federal courts. The limitations on rulemaking imposed by proposed section 2072 therefore protect Congress' prerogatives as to all such cases, not just those in which state law furnishes the rule of decision. Thus, for instance, the legislation is fully operative as to bankruptcy rules, which are fornulated for cases that are within exclusive federal jurisdiction and that are governed largely by federal substantive law.

Third, the limitations on rulemaking in proposed section 2072 protect some lawmaking that has already occurred. In addition and more generally, the limitations reserve for Congress, within its constitutionally pernitted domain, decisions as to whether there should be prospective federal regulation of certam matters and what the content of that regulation should be. Where Congress chooses not to legislate on matters reserved to it by the operation of the limitations on supervisory court rulemaking in proposed section 2072, the deternination whether $\mathrm{m}$ a particular case state law applies or there is pertinent and valid federal law (i.e., federal common law) depends upon other sources of federal lawmaking authority. ${ }^{127}$

Turning to the implementation of the bill's restrictions on supervisory court rulemaking, the Report continues:

Fourth, the substantive rights protected by proposed section 2072 include rights conferred, or that might be conferred, by rules of substantive law, such as "the right not to be injured ... by another's negligence" or the right not to be subject to discrimination in employment on the basis of race. Thus, the bill does not confer power on the Supreme Court to promulgate rules regarding matters, such as limitations and preclusion, that necessarily and obviously define or limit rights under the substantive law. The protection extends beyond rules of substantive law, narrowly defined, however. At the least, it also prevents the application of rules, otlierwise valid, where sucli rules would liave the effect of altering existing remedial rights conferred as an integral part of the applicable substantive law scheme, federal or state, such as arrangements for attorney's fees under 42 U.S.C. 1988. More generally, proposed section 2072 is intended to allocate to Congress, as opposed to the Supreme Court exercising delegated legislative power,

127. Id. at 20-21 (footnotes omitted), with printing errors corrected in 132 CoNG. REc. E-177 (daily ed. Feb. 3, 1986) (remarks of Rep. Kastenmeier). The 1988 House Report also incorporated the corrections by reference. See H.R. REP. No. 889, 100th Cong., 2d Sess. 29 (1988).

Lest I be aceused of being either "muffled" or "obscure," see supra text accompanying note 4, let me remind the reader of my participation in congressional deliberations, public and private, that led to the 1988 legislation amending the Enabling Acts. See supra note *. My views on the proper interpretation of the 1934 Enabling Act and on the changes needed in that legislation emerged from scholarly work completed before I was asked to assist the Congress. See, e.g., Burbank, supra note 9; Burbank, Sanctions in the Proposed Amendments to the Federal Rules of Civil Procedure: Some Questions About Power, 11 Hofstra L. REv. 997 (1983). Indeed, my work is cited twice in the omitted footnotes to the passage quoted in the text. See H.R. REP. No. 422, 99th Cong., 1st Sess. 21 n.7, 22 n.14 (1985). 
lawmaking choices that necessarily and obviously require consideration of policies extrinsic to the business of the courts, such as the recognition or non-recognition of a testimonial privilege. In the absence of congressional choices, prospective regulation is left to the States.

So viewed, proposed section 2072 leaves to the Supreine Court prinary responsibility for prospective federal regulation of niatters peculiarly within the competence of judges. It reserves to Congress decisions concerning prospective federal regulation of matters pecuharly within its coinpetence, having regard to Congress' representative nature and to its experience in prospective lawniaking that variously affects its constituencies in their out-of-court affairs. Further refineinent of the scope of delegation will undoubtedly prove necessary. The Committee beheves, however, that such refineinent should conie in the first instance from those responsible for proposing rules. Conscientious attention to the purposes of, and limitations on, the delegation should prevent controversy of the sort that has plagued federal supervisory court rulenraking in recent years. Such attention by the rulemakers should permit Congress to turn its attention from proposed rules to recommendations for federal legislation on inatters that are beyond the rulemaking power under proposed section 2072 but that nonetheless implicate the interests of the federal courts. ${ }^{128}$

If this House Report explaining the language enacted by Congress is relevant to the interpretation of amended section 2072, it would seem to provide substantial guidance on the questions addressed by Professor Carrington, and in particular to demonstrate that whatever may have been true prior to December 1, 1988, the Supreme Court now lacks the power "to promulgate rules regarding matters, such as limitations and preclusion, that necessarily and obviously define or limit rights under the substantive law."129 Disregard of the House Judiciary Committee's attempt to "take some care in stating its views on the scope of Congress" delegation under proposed section 2072"130 requires either specific evidence that that attempt should not be given weiglit or a general theory to the same effect.

128. H.R. REP. No. 422, 99th Cong., lst Sess. 21-22 (1985) (footnotes omitted).

129. Id. at 21. The Report also observes:

Where Congress chooses not to legislate on matters reserved to it by the operation of the limitations on supervisory court rulemaking in proposed section 2072 , the determination whether in a particular case state law applies or there is pertinent and valid federal law (i.e, federal common law) depends upon other sources of federal lawmaking authority.

Id. (footnote omitted), with printing error corrected in 132 CoNG. REc. E-177 (daily ed. Feb. 3, 1986) (remarks of Rep. Kastenmeier). The footnote, appearing at the end of the quoted sentence, includes a citation to American Pipe, as follows: "American Pipe and Construction Co. v. Utah, 414 U.S. 538 (1974) (federal tolling rule applies to federal statutes of limitations in class action subject to Fed. R. Civ. P. 23)." Id. at 21 n. 10. See supra text accompanying notes 92-103.

For the effective date of the Enabling Act amendments, see Pub. L. No. 100-702, $\S 407,102$ Stat. 4642 (1988).

130. H.R. REP. No. 422, 99th Cong., lst Sess. 21 (1985). 
As to specific evidence, the relevant statutory language remained the same from H.R. 3550 to the legislation that was enacted; the House was responsible for that language, and the 1988 House Report incorporated by reference the 1985 House Report, where the language received close attention. ${ }^{131}$ There was no committee report on the 1988 Senate bill, and in his explanatory remarks, Senator Heflin acknowledged that "the Kastenmeier subcommittee ha[d] been the leader in developing ... a number of significant matters in the bill, such as the titles dealing with arbitration and the rules enabling act amendinents." 132 Moreover, he stated that "[t]he purpose of the amendments to the rules enabling acts is to modernize the statutory framework, respond to criticism surrounding the process and promote openness and participation in the rulemaking process." 133

On the other hand, the section-by-section analysis of the Senate bill stated that subsection 2072(a) "consolidates but carries forward current law"134 and that amended subsection 2072(b) "also carries forward the scope of current law."135 Both references might, but need not, be thought to include judicial interpretations as well as statutory language. In any event, unlike both the 1985 and 1988 House Judiciary Committee reports, which were available to the members of the House (and Senate) prior to the sessions at which action was taken, ${ }^{136}$ this analysis was first

131. See supra text accompanying notes 118-23. "Surely an interpretation placed by the sponsor of a bill on the very language subsequently enacted by Congress cannot be dismissed out of hand ... simply because the interpretation was given two years earlier." United States v. Enmons, 410 U.S. 396, 405 n.14 (1973); see also T.W.A., Inc. v. Civil Aeronautics Bd., 336 U.S. 601, 605-06 n.6 (1949) (adhering to congressional intent apparent from bills preceding those resulting in the Air Mail Act of 1934); Dawson Chem. Co. v. Rohm \& Haas Co., 448 U.S. 176, 204 (1980) (where essence of legislation was unchanged between earlier and later drafts " $t]$ ]he principal sources for edification concerning the meaning and scope of [35 U.S.C.] \$ 271" were hearings on legislative proposals leading to its final enactment); Burbank, supra note 9, at 1098-1101 (discussing relevance of legislative history of bills essentially identical to Rules Enabling Act of 1934).

132. 134 CoNG. Rec. S16,294 (daily ed. Oct. 14, 1988) (remarks of Sen. Heflin).

133. Id. at $\$ 16,295$. The reference to both a purpose to "respond to criticism surrounding the process" and a purpose to "promote openness and participation in the rulemaking process" is significant. The 1985 House Report discussed criticisms of rulemaking relating to notice, access, and participation, as well as those relating to issues of power, under the heading, "Criticism of the rulemaking process." H.R. REP. No. 422, 99th Cong., 1st Sess. 12-14 (1985); supra text accompanying note 125. Moreover, that report identified as separate benefits of H.R. 3550 "promot[ing] openness in the rulemaking process" and "clarif[ying] the limitations on national or supervisory rulemaking by the Supreme Court." H.R. Rep. No. 422, 99th Cong., 1st Sess. 5 (1985).

134. 134 CONG. REC. $\$ 16,300$ (daily ed. Oct. 14,1988 ).

135. Id.

136. See 134 CONG. REc. H7452 (daily ed. Sept. 13, 1988) (remarks of Rep. Kastenmeier) ("For further analysis of each title, I reeommend a reading of the House report that has been available to all Members"). See id. at H7452-53 ("Title I has also passed the House on two previous occasions"). 
available to the members of the Senate during the late evening session when the Senate bill was discussed and approved. ${ }^{137}$

We have, then, a situation in which the body responsible for developing amendinents to legislation sought through detailed legislative history to guard against the assumption that similar statutory language should be given the same meaning by the courts, while the expectations of the other body in that regard remain unclear. ${ }^{138}$

As to a general theory, Professor Carrington notes the "difficulties that inhere in any use of legislative history," 139 as well as difficulties pecuhar to the interpretation of the 1934 Enabling Act in the hight of "long usage." 140 I have previously addressed the latter subject at length, ${ }^{141}$ but, because we are in a new ballgame, both my analysis and Professor Carrington's comments may be irrelevant. Depending on one's view of the specific evidence discussed above, agreennent with Professor Carrington may require rejection of legislative history as an aid to statutory imterpretation, at least in inost cases. There are, of course, those who hold that view, mcluding some in high places. ${ }^{142}$ Although the campaign thus to enpower federal judges at the expense of Congress will doubtless continue, however inconsistently waged, ${ }^{143}$ the Court as a whole has recently "exphicitly reject[ed]" a broad argument against the use of legislative history, reaffirming its "traditional approach" to legislative history as "the sounder and more detnocratic course, the course that strives for allegiance to Congress' desires in all cases, not just those where Congress'

137. Telephone interview with Monique Abacherh, Chief Clerk of the Subcominittee on Courts and Administrative Practice of the Senate Judiciary Committee (Sept. 14, 1989). See also 134 CoNG. REc. S16,294 (daily ed. Oct. 14, 1988) (remarks of Sen. Heflin) ("Because of the limited tine remaining im this Congress, there will not be a committee report accompanymg S. 1482. I will describe the provisions of the bill and then will submit for the record a more lengthy explanation providing background and section-by-section analysis.").

138. H. FRIENDLY, BENCHMARKS 216 (1967) (footnote omitted):

Hence, if an intent clearly expressed in committee reports is withm the permissible limits of the language and no construction manifestly more reasonable suggests itself, a court does pretty well to read the statute to mean what the few legislators having the greatest concern with it said it ineant to them.

Cf. Burbank, supra note 9, at 1101-04 (post-1934 developments, including reenactment, do not signify congressional approval of the Court's interpretations).

139. Carrington, supra note 1 , at 308 (footnote omitted).

140. Id. at 309.

141. See Burbank, supra note 9, at 1098-1106, 1185.

142. See, e.g., Public Citizen v. United States Dep't of Jnstice, 109 S. Ct. 2558, 2574-80 (1989) (Kennedy, J., concurring im judgment); Green v. Bock Laundry Machine Co., 109 S. Ct. 1981, 199495 (1989) (Scalia, J., concurring in judgment). See generally Katzman, Summary of Proceedings, im JUDGES AND LEGISLATORS 170-75 (R. Katzman ed. 1988); Starr, Observations About the Use of Legislative History, 1987 DUKE L.J. 371 (1987); White, supra note 83, at 157-58.

143. Compare Blanchard v. Bergeron, 109 S. Ct. 939, 946-47 (1989) (Scalia, J., concurring in part and concurring in judgment) (criticizing Court's use of legislative history) with Sullivan v. Hudson, 109 S. Ct. 2248, 2258-61 (White, Scalia and Kennedy, J.J., dissenting) (using legislative history). 
statutory directive is plainly sensible or borders on the lunatic."144 Such allegiance seeins particularly fitting here, because the "statutory linitations in question were intended to confine the power of the Court itself." 145

Finally, I turn to Professor Carrington's defense of the Enabling Act's supersession provision. I earher called his proposed interpretation of that clause "ingemious."146 It evidently derives from Professor Carrington's desire to preserve the myth of a uniform, trans-substantive and pohtically neutral procedural system and, as to the last feature, to impart some reality to the myth. The reversal that his proposed interpretation would effect im the respective roles of federalism and allocation of powers under the Enabling Act is as surprising as it is refreshing. ${ }^{147}$ Coming from Professor Carrington, the proposed interpretation is also surprising because it purchases pohitical neutrality at the cost of transsubstantivity. ${ }^{148}$ In any event, Professor Carrington's defense is ahistorical and his proposed interpretation is, I fear, wishful thinking. Moreover, however the clause is interpreted, Professor Carrington's functional defense of supersession does not withstand close scrutiny.

As a matter of history, there is no support for the distinction that Professor Carrington draws among the statutory provisions to be superseded, which would translate "[a]11 laws"149 into "all laws that are not 'arguably substantive.' "150 And what basis is there for his prediction ${ }^{151}$

144. Public Citizen v. United States Dep't of Justice, 109 S. Ct. 2558, 2566 n.9 (1989).

145. Burbank, supra note 9, at 1101; see Mishkin, Some Further Last Words on Erie-The

Thread, 87 HARV. L. REV. 1682, 1687 (1974).

146. See supra text accompanying note 11.

147. See infra text accompanying notes $166,192-94$.

148. See infra text accompanying note 153 .

149. See supra note 5; see also supra note 115.

150. See Carrington, supra note 1, at 325. I leave to the reader whether Professor Carrington's interpretation "comports with the text of the Act." Id.; see also id. at 326.

151. Id. at 325-26 (footnotes omitted) (emphasis added):

To test this formulation, suppose the Supreme Court promulgated new Federal Rules of Civil Procedure bearing generally on the commencement and tolling problems raised by limitations laws, such as late discovery of claims, fraudulent concealment, and mental incompetence of the plaintiff. Would such rules, promulgated by the Court and not opposed by Congress, supersede conflicting provisions set forth in the United States Code? Or, to take a more specific illustration, could the provision of the NLRA requiring service of a summons within a six-month period be superseded by a general rule of court that explicitly imposed the commenceinent-by-filing rule on all federal cases?

I venture negative answers. The NLRA and those who have a stake in it are safe in their interests. On no account would the Court hold that the limitations provisions of the NLRA could be superseded by any general amendments to Rules 3 or 4 . Nor would Rule 3 or 4 be read to "abridge or modify" the Labor Relations Act. This is all sufficiently clear now that the Supreme Court simply assumed it in dealing with the related case of West $\mathrm{v}$. Conrail.

Professor Carrington may here be conflating the issue of supersession and the issue of validity. See infra text accompanying note 163 . 
about the Court's response to conflict between a federal statute containing a provision requiring service to stop the running of the limitations period and Rule 4 or, more likely, ${ }^{152}$ Rule 3, an interpretation of the latter Rule that results in three "plain meanings" and hence in departures from the norm of trans-substantivity beyond that effected by the Court's decisions interpreting the Rule? ${ }^{153}$ Take another hypothetical, one that vividly demonstrates the potential bite of the supersession provision. Are we to beheve that, if the Court had promulgated either the 1983 or 1984 proposal to amend Rule $68,{ }^{154}$ and the proposed Rule had not been blocked by Congress, the Court subsequently would have held that the Rule did not apply in a case governed by an attorney's fee statute? On what basis? Marek v. Chesny, in which the Court read Rule 68 to require denial of post-offer attorney's fees to a plamtiff who would otherwise have received those fees under 42 U.S.C. $\$ 1988$, a subsequently enacted statute, hardly suggests sensitivity either to dissonance between Federal Rules and statutes or to the "arguably substantive" dimensions of legislation? ${ }^{155}$ There is no more reason to believe that the Supreme Court will abnegate power in interpreting the supersession clause, than that it will overrule Hanna.

We should consider-although Professor Carrington does not-the possibility that his interpretation, originally offered before the 1988 legislation, ${ }^{156}$ finds support in that legislation or its history. The text of the supersession clause has remained the same. ${ }^{157}$ The House Judiciary Committee certainly did not share Professor Carrington's narrow view of the "laws" subject to supersession; quite the contrary. ${ }^{158}$ But the House yielded on the retention of the clause. ${ }^{159}$ Again, there was no committee

152. See supra text accompanying note 72.

153. See supra text accompanying notes $85,148$.

154. For a description and critique of these proposals, see Burbank, supra note 8.

155. 105 S. Ct. 3012 (1985).

The Committee disagrees with the Court's decision in Marek v. Chesney, to the extent that Rule 68, as interpreted by the Court, deprives a federal judge of the discretion to award attorney's fees intended to be conferred by 42 U.S.C. 1988. It would be far more difficult for any Court to rcconcile the 1984 proposal [to amend Rule 68] with section 1988, but because of the supersession provision, the attempt need not eveu be made.

H.R. REP. No. 422, 99th Cong., 1st Sess. 13 (1985) (footnotes omitted); see also Burbank, supra note 8, at 437-38.

156. See supra note 2.

157. See supra notes 5 \& 115 .

158. See H.R. REP. No. 422, 99th Cong., 1st Sess. 13 (1985). "[T] he experience with proposed changes in Rule 68 ... demonstrates that the risk of court rules vitiating important Congressional actions on attorney fees-especially in civil rights cases-or other issues is real." Letter from Hon. Robert W. Kastenmeier to Senator Howell Heflin 1 (April 25, 1988) (copy available from author).

159. See 134 CONG. REC. H10,440 (daily ed. Oct. 19, 1988) (remarks of Rep. Kastenmeier) (expressing disappointment with Senate decision to retain supersession clause). 
report in the Senate. In his remarks explaining S. 1482, however, Senator Heflin observed:

The most controversial provision of the rules enabling acts concerns the so-called supersession clause, which is a provision in current law, except with respect to bankruptcy rules.

Under present supersession practice, when a Federal rule conflicts with any procedural component of a previously enacted statute, the rule governs. If the statute has been enacted later than the rule or if the conflict involves substantive rather than procedural rights, then the statute goverus. ${ }^{160}$

This passage in the legislative history might be thought to support Professor Carrington's interpretation. There may, however, be a difference-potentially a big difference-between "substantive" and "arguably substantive" rights or laws. That aside, the passage is not a correct statement of "present supersession practice," that is, of practice under the pre-1988 provision. ${ }^{161}$ Moreover, and in part for that reason, the reference to "substantive rather than procedural rights" suggests that Senator Heflin was conflating the issues of validity and supersession and thus assuring his colleagues, as Professor Carrington has assured us, that "substantive rights established by Congress ... cannot be abridged, enlarged, or modified."162 The other side of the coin, of course, is that if a Federal Rule is valid under the Enabling Act-the Supreine Court lias never invalidated a Federal Rule of Civil Procedure-there is no barrier to supersession. Such conflation is common. ${ }^{163}$

Finally, a related point: the passage gives evidence of a sin akin to that which Professor Carrington, following Walter Wlieeler Cook, has deplored.164 Here, lowever, the problem is not the assumption that "procedure" and "substantive riglits" liave the same ineaning when used

160. 134 CoNG. REC. S16,296 (daily ed. Oct. 14, 1988) (remarks of Sen. Heflin).

161. See supra text accompanying notes $149-50$; infra note 203 and accompanying text.

162. Carrington, supra note 1 , at 323 .

163. See supra note 151. In a letter that was influential to the decision in the House not to insist on the deletion of the supersession clause, see infra text accoinpanying note 178, Chief Justice Rehnquist made the same linkage, observing:

The Judicial Conference and its committees on rules have participated in the rules promulgation process for over a half century. During this time they have always been keenly aware of the special responsibility they have in the rules process and the duty incumbent upon them not to overreach their charter. The advisory committces should undertake to be circumspect in superseding procedural statutes.

Letter from Hon. William H. Rehnquist to Hon. Peter W. Rodino, Jr. (Oct. 19, 1988), reprinted in 134 CONG. REC. H10,441 (daily ed. Oct. 19, 1988) [hereinafter cited as Rehnquist letter].

As to the factual assertions in the Chief Justice's letter, rulemaking was not committed to the "Conference and its committees" until 1958, see Pub. L. No. 85-513, 72 Stat. 356 (1958) (codifled at 28 U.S.C. $\S 331$ (1982)) and the rulemakers have not "always been keenly aware of ... the duty incumbent upon them not to overreach their charter." See, e.g., Burbank, supra note 9, at 1131-37.

164. See Carrington, supra note 1, at 284-85; infra text accompanying note 218. 
for different purposes, but that they have the same meaning to different speakers for the same purpose. The problem arises because, as the experience with proposals to amend Rule 68 demonstrates, lawmaking often involves a choice between policies that all would agree are procedural (i.e., docket-clearing) and those that all would agree are substantive (i.e., encouraging enforcement of federal law by private plaintiffs). The view one takes of the product of the lawmaking enterprise-is the provision procedural or substantive?-is likely to depend on the policies that triumph in the process. ${ }^{165}$

I will not elaborate other objections to Professor Carrington's proposed interpretation of the supersession clause, including the objection that it might encourage continuing neglect of the Act's basic restrictions on court rulemaking, particularly as regards state law cases. ${ }^{166}$ Nor will I elaborate possible constitutional objections to the supersession clause itself, which is hard to square with the vision of separation of powers projected by INS v. Chadha. ${ }^{167}$ Legislation is legislation, no matter how we choose to characterize it. ${ }^{168}$ In an age of both computerized statutes and court rules that eschew policy choices, ${ }^{169} \mathrm{I}$ have yet to hear a good argument why those rules should not be assimilated to, that is, treated like federal common law, at least in the requirement that they respect Congress' pohicy choices. ${ }^{170}$ Having read Professor Carrington's discussion of the "three functions" of supersession, ${ }^{171}$ I am still waiting.

According to Professor Carrington, supersession is "functionally linked to the requirement that rules be reported to Congress." 172 This, of course, is not an independent argument in favor of supersession. Moreover, there was no link at all between the supersession clause and that requirement historically. Supersession first appeared in a bill to grant the

165. See Burbank, supra note 8, at 435-39; supra note 158. Thus, a major benefit of repeal of the supersession clause would be to render the procedure/substance dichotomy irrelevant in the event of incousistency between a federal statute and a subsequently promulgated Federal Rule. Its retention puts a greater premium on attention to the Act's basic restrictions, if not by the rulemakers, then by Congress. See infra text accompanying note 198.

166. See infra notes 192-94 and accompanying text. More generally, Professor Carrington's interpretation, if adopted, unight reinforce the erroneous interpretation of the Act's basic restrictions as concerned with the proteetion of existing policy choices rather than with the allocation of power to make policy choices. See supra text accompanying notes 16,31 .

167. 462 U.S. 919 (1983).

168. See id. at 954 (footnote omitted) ("Amendment and repeal of statutes, no less than enactment, unust conform with Art. I"); id. at 954 n.18, 958 n.23.

169. See Burbank, Rules and Discretion, supra note 13, at 715.

170. See Burbank, supra note 8, at 437; Burbank, supra note 9, at 1193.

171. Carrington, supra note 1 , at 322-24.

172. Id. at 322. As amended in 1988, the reporting requirement provides for a layover period of seven months (May 1 to December 1), not six. Compare id. at 323 ("six-month window of time") with Pub. L. No. 100-702, $\S 401$ (a), 102 Stat. 4642,4649 (1988) (to be codified at 28 U.S.C. $\S 2074$ ). 
Court rulemaking power for actions at law in $1914 ;{ }^{173}$ the reporting provision appeared ten years later in connection with the expansion of the grant to authorize a merged system of law and equity rules. ${ }^{174}$ They were thought to serve wholly distinct purposes. ${ }^{175}$ Nor is there any contemporary functional link, although Professor Carrington argues to the contrary. As he would have it, reporting serves to alert Congress to the potential for supersession. Without supersession, there would be no need for reporting. ${ }^{176}$

Reporting can "assure[ ] congressional knowledge of, and passive acceptance of any supersession" 177 only if the rulemakers are scrupulous m identifying statutory provisions that would be superseded by proposed Federal Rules or amendments. Happily, Chief Justice Rehnquist has assured the Congress that the rulemakers will be scrupulous in the future, an assurance that may have been essential to the passage of the 1988 legislation. ${ }^{178}$ The Chief Justice's assertion that such had been "generally the approach . . . undertaken in the past" 179 is, however, sheer revisiomism. One looks in vain for statements in the materials accoinpanying the Appellate Rules ${ }^{180}$ that they would have the superseding effects subsequently imputed to them in the cases cited by Professor Carrington. ${ }^{181}$ More ominously, the recently circulated preliminary draft of a proposed amendment to Rule 84 and proposed practice manual did not remark on the inconsistency between those proposals and both 28 U.S.C. $\S 2072$ and $\S 2074 .{ }^{182}$ Because knowledge of a proposed supersession may be

173. For the history and anticipated function of the supersession clause, see Burbank, supra note 9, at 1052-54.

174. For the history of and original reasons for the reporting requirement, which was written by Chief Justice Taft, see id. at 1074-76.

175. See sources cited supra notes 173-74. Although there was an argument to be made, and Dean Clark made it with typical tenacity, that the 1934 Enabling Act did not require the reporting of amendments to Congress, Congress was assured that they would be reported and relied on that assurance. See Burbank, supra note 9, at 1153-54 n.601.

176. See Carrington, supra note 1, at 322-23.

177. Id. at 322-23.

178. See Rehnquist letter, supra note 163.

179. Id..

180. See 9 J. MOORE \& B. WARD, MOORE's Federal Practice $\{204.01[2]$ (1989) (Advisory Committee Nore to FED. R. APP. P. 4(a)); id. at ๆ 239.01[2] (Advisory Committee Note to FED. R. APp. P. 39). See id. at If 201.07 ("the Appellate Rules do not list all of the statutes that they supersede ... Compiling such a hist would have involved an arduous search of the United States Code ....").

181. See Carrington, supra note 1, at 321-22 and cases cited in id. at 320-22 nn.250-54.

182. See Committee on Rules of Practice and Procedure of the Judicial Conference of the United States, Preliminary Draft of Proposed Amendments to the Federal Rules of Criminal Procedure and the Federal Rules of Civil Procedure 15-37 (March 1989). For an analysis of the inconsistencies, see Letter from Stephen B. Burbank to Committce on Rules of Practice and Procedure (June 21, 1989) (copy available from author). 
essential to informed public comment, it is liard to believe that the rulemakers were simply liolding back until a later stage. More likely, they simply did not notice. The fact is that, at least in recent years, the ruleinakers liave evinced a slrocking ignorance of, or disregard for, statutory law. ${ }^{183}$ Professor Carrington's article suggests his good intentions witll respect to legislation, but his treatinent of the 1983 legislation amending Rule $4^{184}$ and indeed of the 1988 legislation amending the Enabling Acts ${ }^{185}$ are like tlie stroke of the thirteently lour, casting doubt on all that comes before. In any event, one individual's good intentions are liardly a firm basis for enduring public policy.

The notion tliat reporting is "not necessary to protect substantive rights establislied by Congress, for tliese cannot be abridged, enlarged or inodified" 186 at least lias historical lineage, lowever dubious, ${ }^{187}$ but it is liardly what one would expect froin a follower of Walter Wheeler Cook. Again, notwitlistanding the assurances given to Congress in 1938 that the Court would be "zealous to correct [a] mistake, if any lias been made," 188 the Court lias never invalidated a Federal Rule of Civil Procedure. Even the Court now acknowledges tliat some of its work, notably the 1966

\footnotetext{
The proposed amendment to Rule 84 would thus grant power to the Judicial Conference that it does not currently possess, to wit, the power to promulgate new or amended Administrative Rules. In that aspect, the proposed rule would partially supersede $\$ 2072$, substituting the Conference for the Court, and $\$ 2074$, dispensing with submission to Congress. Moreover, by reason of Rule 84, such Administrative Rules would have the effect of superseding inconsistent local rules .... I have serious doubts whether such a grant of rulemaking power can be accomplished by Federal Rule.
}

Id. at 3. See also id. at 4 ("At the least, [the Conference] should honor the Chief Justice's assurance that, in proposing Federal Rules that would supersede Acts of Congress, the rulemakers 'will undertake to identify such situations when they arise ... . " ").

The proposals have since been "referred to the Advisory Committee on Civil Rules for further study and consultation with Circuit Executives in light of the comments received from a number of district judges and members of the bar." Letter from Hon. Joseph F. Weis, Jr. to Hon. Robert W. Kastenmeier (Aug. 21, 1989) (copy available from author).

183. See, e.g., Burbank, supra note 127, at 1003-04 (in amending Rule 11, rulemakers proceeded in apparent ignorance of congressional concern about impact of sanctious on attorneys' effective representation, expressed when Congress amended 28 U.S.C. $\$ 1927$; 128 CoNG. REC. 30,930-31 (1982) (remarks of Rep. Edwards) (asserting failure of proposed amendment to Rule 4 to achieve its purpose in light of statutes).

184. See supra notes $79-80$ and accompanying text.

185. See supra text accompanying notes 111-45, 156-65.

186. Carrington, supra note 1 , at 323 ; see supra text accompanying note 162 .

187. See Burbank, supra note 9, at $\mathbf{1 1 3 7}$ (footnotes omitted):

In various public pronouncements during the drafting of the Rules and their consideration by Congress, members of the Advisory Committee assured their audiences that the task of observing the procedure/substance dichotomy had proved not very difficult. The truth, however, was that, having failed to address the problem at all systematically, the Committee was forced, and in most cases was quite content, to rely largely on judgments informed by a sense of the professional and political chimate and by the hope that the Supreme Court would preserve it from error.

See also id. at 1134-35 n.530.

188. See supra text accompanying note 53. 
amendments to Rule 23, has been "substantive ... in the sense that the rules of procedure have important effects on the substantive rights of litigants," 189 and for years many scholars have regarded the reporting provision as an important check on overreaching. ${ }^{190}$ So, indeed, has the Court itself. ${ }^{191}$ The Enabling Act, both in 1934 and today, protects not only substantive rights that have been "established by Congress." It protects Congress's power to decide whether there shall be prospective federal law in a given area. If Congress decides not to act in that area, the Enabling Act protects rights that have been, as well as rights that inight be, conferred by state law. ${ }^{192}$ As Professor Carrington acknowledges, supersession is irrelevant with respect to state law. ${ }^{193}$ Although it is heartening that he recognizes at least some of the Enabling Act's implications for separation of powers, we should not forget either that federalism has dominated debates about rulemaking power for the last fifty years or that federalism remams a concern, even if only derivatively. ${ }^{194}$ Under Professor Carrington's view of the reporting requirement, who would watch the watchmen when the concern was the inappropriate displacement of state law?

The possibility of supersession may furnish an additional "inducement" to those who "perceive that their substantive interests are threatened by a proposed amendment, to marshal their political resources for self-protection." ${ }^{195}$ But neither the part of our legal landscape occupied by federal as opposed to state law, the appearance of political neutrality that Professor Carrington so values in Federal Rules, ${ }^{196}$ nor the rulemakers' track-record in alerting interested parties

189. Mistretta v. United States, 109 S. Ct. 647, 665 (1989) (footnote omitted) (“[T] his Court's rulemaking under the enabling acts has been substantive and political in the sense that the rules of procedure have important effects on the substantive rights of litigants."); see also id. at $665 \mathrm{n}, 19$ (describing the controversy surrounding Rule 23). So inuch for "incidental effects." See Carrington, supra note 1, at 298-99; supra note 37.

190. See, e.g., W. Brown, Federal Rulemaking: Problems and Possibilities 86-96 (1981) (noting that the negative aspects of congressional review might be avoided by a closer relationship between the judicial and legislative branches in the drafting and revision processes). By no ineans, however, is it a sufficient check. See Burbank, supra note 9, at 1196 \& n.779 ("[T]he congressional review mechanism ... is an inperfeet instrument for the protection of rights and interests far removed from the domain of procedural expertise.").

191. See Hanna v. Plumer, 380 U.S. 460, 471 (1965); see also Burlington N.R.R. v. Woods, 480 U.S. 1, 6 (1987) (reporting requirement cited as one basis for "presumptive validity" of proposed Federal Rules); Sibbach v. Wilson \& Co., 312 U.S. 1, 15-16 (1941) (congressional examination of proposed rules and laws is frequently enployed to make sure action "squares with the Congressional purpose"); Burbank, Rules and Discretion, supra note 13, at 700 \& n.53; supra note 54.

192. See supra text accompanying notes $46-47$.

193. See Carrington, supra note 1 , at 322 .

194. See supra text accompanying notes 22-49; supra note 40; Burbank, supra note 9, at 1187.

195. Carrington, supra note 1 , at 323.

196. See id. at 301-02. 
to the possibility of supersession ${ }^{197}$ suggests that it is of much practical importance in that regard. Moreover, the argument is not what one would expect from one who has asserted both that reporting is not necessary to protect substantive rights, and that "arguably substantive" statutes are not subject to supersession.

In the absence of serious and sustained attention to the Enabling Act's limitations by the rulennakers and the Court, reporting reinains "an important check on overreaching." 198 It would remain important even if there were no supersession clause, if ouly because existing congressional statutes embody ouly some of the substantive rights protected by those limitations. Far from providing "focus for congressional review," 199 the supersession clause increases the pressure on Congress to delay or defeat the effectiveness of proposed Federal Rules reported to it and thus inakes it harder for Congress to achieve an important goal of the 1988 annendments to the Enabling Acts: "prevent[ing] controversy of the sort that has plagued federal supervisory court rulemaking in recent years." ${ }^{200}$

Professor Carrington's second functional justification of supersession is on sounder ground historically, but it rests on questionable factual and theoretical premises. According to that justification, supersession permits the rulemaking process to "clear away from the timbers of important and enduring federal legislation the undergrowth of procedural marginalia that have been attached to legislation for faded or forgotten reasons."201 And, according to Professor Carrington, it does so only with "notice to Congress" and only with respect to "matters of "practice and procedure' having no substantive consequences."202

\footnotetext{
In effect, Professor Carrington identifies as "political" only that which is recognized as of interest by some coherent (and, apparently, wholly self-interested) group. According to this view, "neutrality" means "reduc[ing] the level of political interest in procedural rules." And according to this view, both substance-specific procedures and empirical investigation of supposedly neutral rules are anathema: the former because they will be likely to attract rather than "deflect political attention" and the latter because data on experience under the Rules may cause organized groups to realize that they have a stake and hence to regard the "neutral" rule as a legitimate object of political interest.

Burbank, Transformation, supra note 13, at 1936-37 (footnotes omitted).

197. See supra text aecompanying notes 177-85.

198. See supra text accompanying note 190.

199. Carrington, supra note 1 , at 323.

200. H.R. REP. No. 422, 99th Cong., 1st Sess. 22 (1985); see also id. at 13. "[T]he mere existence of the supersession clause has been a factor that has motivated the Congress-especially the House- to intervene anore than 20 times in the past to delay the effective date or to reject proposed rules." Letter from Hon. Robert W. Kastenmeier to Senator Howell Hefin, supra note 158, at 1.

If the Supreme Court follows Professor Carrington's lead in ignoring the legislative attempt to confine the Court's supervisory rulemaking power, the goal of avoiding controversy is doomed both when supersession is implicated and when it is not. See Burbank, supra note 9, at 1195-96; supra
} note 165 .

201. Carrington, supra note 1, at 324.

202. Id. 
As originally formulated, the supersession clause was intended to "clear . . . undergrowth," although it was by no means limited to "procedural marginalia."203 Nor is it so limited today, even if Professor Carrington could persuade the courts to adopt his novel interpretation of the supersession clause and read "[a]1l laws" to mean "all laws that are not 'arguably substantive." "204 Failing that, a valid Federal Rule of Civil Procedure will supersede even a statutory provision that Members of Congress regard as conferring a substantive right. ${ }^{205}$ Congress may not receive notice of the potential for supersession. If it does receive notice, there will be additional pressure to intervene, because, apart from the ineffectiveness of judicial review for consistency with the Enabling Act, on this hypothesis only Congress can prevent supersession.

The notion that, in 1989, the statutory provisions at risk of supersession consist primarily of "procedural marginalia" is, in any event, hard to accept. Congress conducted a general ground-clearing operation when it revised the Judicial Code in $1948,{ }^{206}$ and the examples of supersession adduced by Professor Carrington are telling precisely because they involve Federal Rules that did not come imto effect until 1968.207 If, as the Supreme Court has assured us, Congress legislates against the background of Federal Rules and does not lightly seek their displacement, ${ }^{208}$

203. As one example, a major purpose of the supersession clause was to free the federal courts from the obligation to apply state law imposed by the Conformity Act of 1872. See Burbank, supra note 9, at 1052-54; supra text accompanying note 17. As another, the original Advisory Committee apparently hoped that original Rule 83 would both "abolish" any vestiges of the Conformity Act and supersede the requirement, see 28 U.S.C. $\$ 2071$ (1982), that local rules of court be consistent with federal statutes. See Letter from William D. Mitchell to Charles E. Clark (Oct. 13, 1937) (Clark Papers, Sterling Library of Yale University, box 111, folder 58); Letter from Stephen B. Burbank to Committee on Rules of Practice and Procedure 4-5 (Feb. 27, 1984), reprinted in 1985 Hearing, supra note *, at 27-28. The latter goal was not achieved. See Colgrove v. Battin, 413 U.S. 149, 161 n.18 (1973). The examples can be multiplied simply by reviewing the Advisory Committee's Notes to the 1938 Rules, specifying some of the statutes superseded or partially superseded. The effects on existing statutes of original Rule 4(f) (territorial limits of effective service), Rule 25 (substitution of parties), and Rule 43 (evidence) are of particular interest. See Burbank, supra note 9, at 1172-73 n.673 (Rule 4(f)), 1155-57 (Rule 25), and 1137-43 (Rule 43).

204. See supra text accompanying notes 149-65. The statutes that would have been partially superseded by the reeently proposed amendment to Rule 84 and proposed practice manual, 28 U.S.C. $\$ \S 2072,2074$ (1982 \& Supp. V 1988), are hardly "procedural marginalia." See supra text accompanying note 182 .

205. See supra text accompanying notes $158,163-65$.

206. Letter from the Hon. Edward T. Gignoux to Hon. Robert W. Kastenmeier 1 (Sept. 24, 1985), reprinted in H.R. REP. No. 422, 99th Cong., 1st Sess. 44 (1985); see also id. at 23..

207. See Carrington, supra note 1, at 322 (citing "the extension of time for appeal, the taxability of printing costs, and proctors' fees in admiralty appeals" as examples); supra text accompanying notes 180-81.

208. See, e.g., Califano v. Yamaski, 442 U.S. 682, 698-701 (1979) (ruling that, in the absence of clear expression of congressional intent to the contrary, availability of class relief under statute should be governed by Rule 23); see also Walsh v. Ford Motor Co., 807 F.2d 1000, 1006-11 (D.C. 
there should be very few statutory provisions remaining that are inconsistent with Federal Rules. And if so, it is hard to understand why Congress' stated reason for repealing the supersession clause for Bankruptcy Rules in the Bankruptcy Reform Act of $1978^{209}$ is not generally applicable. As explained in the Senate Report: "This bill extensively revises the bankruptcy law. Nearly all procedural matters have been removed and left to the Rules of Bankruptcy Procedure. Consequently, the need to permit the Supreme Court's rules to supersede the statute no longer exists. To the extent a rule is inconsistent, the statute will govern."210

If the Court is right about Congress's general attitude, those few cases where supersession remains possible are likely to involve inconsistency resulting froin an advertent exercise of policy judgment by Congress in the face of a contrary policy judgment by the rulemakers. In this context, the question of supersession is whether the rulemakers should be able to coine back with a rule reasserting their policy preference, or asserting a wholly new policy preference, and thus require Congress again to pass, and the President again to sign, legislation in order to prevail. Professor Carrington praises supersession as "contribut[img] over time to the maintenance of rules that are general and a rulemaking process that is appropriately neutral."211 Inpleinenting the work of one who advocates a "veil of ignorance"212 that would shield the rulemakers from the possible substantive side effects of their rules, the supersession clause also deprives Congress of the ability to respond, discretely and effectively, to proof of disproportionate substantive impact-and all in the service of rules whose uniformity, trans-substantivity, simplicity, and predictability are a inirage. ${ }^{213}$

Professor Carrington's final functional justification of supersession is that it "signif[ies] one aspect of the relationship between Congress and the federal courts as co-equal branches of the government."214 As that

Cir. 1986) (nothing in Magnuson-Moss Act compelled trial court to "bend the requirements of Rule 23"), cert. denied, 482 U.S. 915 (1987).

209. Pub. L. No. $95-598, \S 247,92$ Stat. 2549,2672 (codified as amended at 28 U.S.C. $§ 2075$ (1982)). The 1988 legislation did not alter these arrangements.

210. S. REP. No. 989, 95th Cong., 2d Sess. 158 (1978); see also H.R. REP. No. 595, 95th Cong., 1st Sess. 292-93 (1978) ("[T] Re Rules would no longer create confusion if they are inconsistent with the statute, and the Supreme Court will lose the power to repeal pro tanto portions of the bankruptcy laws.").

211. Carrington, supra note 1 , at 324 .

212. Carrington, Bogy, supra note 3, at 2079. For criticism of this proposed normative posture for rulemakers, see Burbank, Transformation, supra note 13, at 1940-41.

213. See Burbank, Transformation, supra note 13, at 1929-43. I am assuming that Professor Carrington's unique interpretation of the clause will not be adopted. See supra text accompanymg notes 149-55.

214. Carrington, supra note 1 , at 324 . 
justification may suggest, the view one takes of supersession may ultimately depend on the value one places on symbols. I am uncomfortable with the messages conveyed by the supersession clause, but it at least once served a useful purpose. ${ }^{215}$ Today, as I have suggested, one message may be that notwithstandimg the Chief Justice's reassuring words, the rulemakers need not be concerned about Congress's policy choices as they go about their work. ${ }^{216} \mathrm{~A}$ far more troublesome message is that the policy preferences of judges and their advisers, acting in a legislative capacity but without popular mandate or all of the restraining influences of the legislative process, are entitled to supremacy when they conflict with the policy preferences of the people's representatives. Whether or not the supersession clause is consistent with the formal requirements of the Constitution, it is not, at least for me, consistent with the vision of a democratic society that inspires that document.

History alone does not permit us to assume that future Reporters will share Professor Carrington's qualities. Those qualities, however, have already served the rulemaking process well. We can only hope that in shaping the procedure of the twenty-first century even greater attention will be paid to the concern that, if the rulemakers are left to make choices as to matters that are rationally capable of classification as either procedure or substance, "they will choose to advance those policies that are their special province and to subordinate those that are not."217 Perhaps that hope too is wishful thinking, but with me it has "all the tenacity of original sm."218

215. See supra text accompanying note 203.

216. See supra text accompanying notes 178-85.

217. Burbank, supra note 9 , at 1191-92.

$$
\text { fin } 1 \text { n tin } 1 \text { f. } 1 \text { it }
$$$$
3 \mathrm{~m}_{\mathrm{j}} \quad r^{\mathrm{nmt}} \quad \mathrm{ta}
$$$$
.22 \quad-\operatorname{tm} 38 \quad 1_{s u} N w^{\mathrm{U}}
$$ 